\title{
HYPEROSTOSIS FRONTALIS INTERNA ON THE SKELETAL REMAINS OF THE SARMATIANS OF THE LOWER VOLGA AND THE LOWER DON (TO THE QUESTION OF CAUSES OF THE ENDOCRINE DISORDERS IN THE EARLY IRON AGE) ${ }^{1}$
}

\author{
Evgeniy V. Pererva \\ Volgograd Institute of Management - Branch of Russian Presidential Academy of National Economy \\ and Public Administration, Volgograd, Russian Federation
}

Vladimir I. Moiseev

Volgograd State University, Volgograd, Russian Federation

\begin{abstract}
Introduction. The field of paleopathology, which studies the diseases of ancient people, makes important contribution to the reconstruction of the lifestyle and history of the Sarmatian nomads. When examining human bone remains, such a pathological condition as the hyperostosis frontalis interna (HFI) is sometimes revealed on the frontal bone from the endocranium. Today, most physisians and paleopathologists believe that this condition is the result of the Morgagni-Stewart-Morel syndrome, which stimulates the development of endocrine disorders in the human body.

Methods and materials. The research material is represented with the skulls of Sarmatian nomads from the burial grounds of the Lower Volga and the Lower Don. A total of 465 craniums have been examined. The degree of frontal hyperostosis development has been assessed by the method of I. Hershkovitz, et al. [92].

Analysis. As a result of the analysis of bone material, 35 cases of the HFI have been recorded on the Sarmatian skulls. Genetic predisposition, specific lifestyle (nomadism), unhealthy and unsystematic diet (high content of proteins and fats, periods of hunger alternated with overeating periods), psycho-emotional disorders typical of the nomads of the early Iron Age were, most likely, the determining factors stimulating the development of endocrine disorders markers.

Results. We've come to the conclusion that, as opposed to the modern character of the disease spreading, which is more typical for women aged 45-60, this deviation in Sarmatians is more common in men. The analysis of written, ethnographical and archaeological sources, the study of medical and paleopathological literature allows assuming that the HFI in the Sarmatians of the Lower Volga and the Lower Don could develop as a result of the abovementioned factors.

E. V. Pererva has carried out the the paleopathological study of materials and the comparison of the obtained results with domestic and foreign works in the field of medicine and anthropology. V. I. Moiseev has interpreted the obtained results in the context of written and archaeological sources.

Key words: Sarmatians, hyperostosis frontalis interna, Morgagni-Stewart-Morel syndrome, endocrine $\infty$ disorders, lifestyle.

Citation. Pererva E.V., Moiseev V.I. Hyperostosis Frontalis Interna on the Skeletal Remains of the Sarmatians of the Lower Volga and the Lower Don (to the Question of Causes of the Endocrine Disorders in the Early Iron Age). Vestnik Volgogradskogo gosudarstvennogo universiteta. Seriya 4, Istoriya. Regionovedenie. Mezhdunarodnye otnosheniya [Science Journal of Volgograd State University. History. Area Studies. International Relations], 2018, vol. 23, no. 6, pp. 18-43. (in Russian). DOI: https://doi.org/10.15688/jvolsu4.2018.6.2
\end{abstract}


Е.В. Перерва, В.И. Моисеев. Внутренний лобный гиперостоз на костных останках сарматов

Дата поступления статьи: 16.03.2018

ББК $63.4,28.7$

Дата принятия статьи: 10.10.2018

\title{
ВНУТРЕННИЙ ЛОБНЫЙ ГИПЕРОСТОЗ НА КОСТНЫХ ОСТАНКАХ САРМАТОВ НИЖНЕГО ПОВОЛЖЬЯ И НИЖНЕГО ДОНА (К ВОПРОСУ О ПРИЧИНАХ ПРОЯВЛЕНИЯ ЭНДОКРИННЫХ НАРУШЕНИЙ У КОЧЕВНИКОВ РАННЕГО ЖЕЛЕЗНОГО ВЕКА) ${ }^{1}$
}

\author{
Евгений Владимирович Перерва \\ Волгоградский институт управления - филиал Российской академии народного хозяйства \\ и государственной службы (РАНХиГС), г. Волгоград, Российская Федерация \\ Владимир Иванович Моисеев \\ Волгоградский государственный университет, г. Волгоград, Российская Федерация
}

\begin{abstract}
Аннотация. Для реконструкции образа жизни и истории сарматских кочевников существенный вклад имеет такое научное направление как палеопатология, изучающая болезни древних людей. При исследовании костных останков человека на лобной кости с внутренней ее стороны иногда выявляется такое патологическое отклонение, как внутренний лобный гиперостоз. В настоящий момент большая часть врачей и палеопатологов считают, что данное состояние является результатом формирования синдрома Морганьи - Стюарта - Мореля, стимулирующего развитие эндокринных нарушений в организме человека. В результате проведенного исследования 469 черепных коробок сарматского времени было выявлено 35 случаев внутреннего лобного гиперостоза. Оказалось, что в отличие от современной картины распространения заболевания, которое в большей степени характерно для женщин 45-60 лет, данное отклонение у сарматов чаще встречается у мужчин. Анализ письменных, этнографических и археологических источников, изучение медицинской и палеопатологической литературы позволяет сделать предположение, что внутренний лобный гиперостоз у сарматов Нижнего Поволжья и Нижнего Дона мог развиваться в результате наследственной предрасположенности, негативного воздействия специфического образа жизни, рациона питания и психоэмоциональных перегрузок.

Е.В. Перерва в данной работе отвечал за палеопатологическое исследование материалов и сопоставление полученных результатов с отечественными и зарубежными работами в области медицины и антропологии.

В.И. Моисеев ответственен за интерпретацию полученных результатов в контексте письменных и археологических источников.

Ключевые слова: сарматы, внутренний лобный гиперостоз, синдром Морганьи - Стюарта - Мореля, эндокринные нарушения, образ жизни.

Цитирование. Перерва Е. В., Моисеев В. И. Внугренний лобный гиперостоз на костных останках сарматов Нижнего Поволжья и Нижнего Дона (к вопросу о причинах проявления эндокринных нарушений у кочевников раннего железного века) // Вестник Волгоградского государственного университета. Серия 4, История. Регионоведение. Международные отношения. - 2018. - Т. 23, № 6. - C. 18-43. - DOI: https://doi.org/ 10.15688/jvolsu4.2018.6.2
\end{abstract}

Введение. Эндокринная система человека состоит из нескольких желез внутренней секреции, основной задачей которых является выработка гормонов. Гормоны это эндогенные химические соединения, которые образуются в теле человека или в его железах, переносятся по крови и влияют на ростовые и метаболические процессы, синтез белков, половое развитие, а также оказывают воздействие на выполнение других различных функций в организме. Основны- ми причинами практически любых эндокринных заболеваний являются: дефицит гормона, его избыток, продукция аномального гормона, резистентность к действию гормона, нарушение транспорта, метаболизма или ритма секреции гормона, а также одновременное нарушение ряда гормональных систем $[19$, с. 40$]$.

Эндокринные заболевания очень редко диагностируются при изучении человеческих останков биоархеологами. Палеопа- 
тологами на антропологических материалах определяются далеко не все заболевания, которые могли быть спровоцированы нарушениями эндокринной системы. В энциклопедических работах приведены случаи развития патологий на костях, которые соотносятся с такими отклонениями, как гиперпитуитаризм (гиперфункция гипофиза), гипопитуитаризм (недостаточность функции гипофиза), гипертириоз (синдром, обусловленный повышением активности щитовидной железы), тиреотоксикоз, гипотиреоз (снижение активности щитовидной железы), с расстройствами гипофиза связывают гиперостоз эндокранной поверхности лобной кости, болезнь Педжета $[102 ; 105 ; 111]$.

На антропологических материалах с территории Нижнего Поволжья и Нижнего Дона наиболее часто встречаемым отклонением, которое можно отождествить с эндокринными нарушениями в организме человека, является внутренний лобный (фронтальный) гиперостоз (далее - ВЛГ). Внутренний лобный гиперостоз определяется как утолщение лобной кости, внутренняя ее поверхность становится бугристой. Обычно фиксируется линия соединения сохранившейся кости и новообразованной [54, c. $106 ; 103$, p. $58 ; 105$, p. $247 ; 111$, p. 419].

Современными врачами ВЛГ связывается с развитием у человека синдрома Морганьи - Стюарта - Мореля [14; 22; 31, с. 72; 63]. Впервые данный синдром в научной литературе описал итальянский анатом и патолог Джованни Батиста Морганьи в 1761 году. После вскрытия тела 40-летней женщины ученый установил на черепе утолщения лобной кости, а также наличие ожирения и вирилизма [81, p. 45]. Более чем через 150 лет английский невролог Р.М. Стюарт и швейцарский врач Ф. Морель независимо друг от друга, исследовав несколько случаев лобного гиперостоза в клиниках у психически больных людей, предложили считать основными признаками развития синдрома наличие фронтального гиперостоза, эндокринных и нейропсихиатрических нарушений, которые могут сопровождаться ожирением и аменореей [54, с. 106; 110 , p. $42 ; 111$, p. 419; 114, p. 78-79].

В настоящее время исследователи указывают, что наряду с ожирением и вирилизмом данное расстройство может сопровож- даться психическими и неврологическими синдромами, депрессией, эпилепсией, аутоиммунными заболеваниями, ревматоидной инфекцией, системной склеродермией, закрытой черепно-мозговой травмой $[14 ; 22]$. Некоторые исследователи указывают на следующие основные симптомы данного заболевания у современного человека: ожирение, упорную головную боль, повышение артериального давления $[22 ; 43$, с. $27 ; 75$, с. 215$]$

Этиология лобного гиперостоза до сих пор точно не установлена. Появление данного состояния исследователи связывают с разными причинами: ожирением, расстройствами половой системы и диабетом, гиперпаратиреоидизмом [92, р. 322-323]. Есть мнение, что ВЛГ является половозрастным феноменом, так как признаки данного отклонения клинические врачи и палеопатологи чаще встречают у зрелых женщин [82, p. 703; 91, p. 172] в постменопаузальный период [85; 94, p. 1078; 96 , p. $671 ; 108$, p. $208 ; 109$, p. $17 ; 116$, p. 102]. В то же время синдром отмечается и у мужчин [105, p. 250]. С. Смит, Р. Хемпфил, а также Т. Хокинс и Л. Мартин, исследовав в различных клиниках Англии и США женские группы с внутренним лобным гиперостозом, пришли к выводу, что он может сопровождаться психическими и эндокринными нарушениями [91, с. 171-174; 110, p. 45]. Об эндокринной природе данного синдрома высказывались И. Гершкович и др. [92], Х. Май и др. [97], Ф. Атанасио и др. [80] и многие другие. Д. Ортнер и В. Путчар указали, что развитие лобного гиперостоза связано с нарушениями продуцирования гормонов гипофизом [102, р. 294]. Высказано предположение, что недостаток женского полового гормона у женщин и избыток его у мужчин, вероятно, провоцируют проявление данного маркера [10, с. 36-37]. О связи ВЛГ с такими эндокринными расстройствами, как акромегалия, гипотериоз и болезнь Педжета, указывали А. Ауфдерхейде и К. Родригез-Мартин [111, р. 419], Е. Чуда и др. [83], Г.А. Баранова [7] и др. Существует предположение о генетической предрасположенности к развитию ВЛГ [12; 93, р. 59].

Изначально в палеопатологической науке исследование внутреннего лобного гиперостоза затруднялось тем обстоятельством, что патология могла быть обнаружена только в 
случае рентгенологического исследования целой черепной коробки или в процессе изучения фрагментов мозговой капсулы, где эндокранная поверхность лобной кости находится в хорошей сохранности. В связи с этим первоначально работ по исследованию данного патологического состояния было сравнительно немного. Также ряд исследователей, ссылаясь на работы И. Гершковича [92] и Х. Май [97], указывают на то, что частота встречаемости признаков синдрома Морганьи - Стюарта - Мореля у современного населения несколько выше по сравнению древними популяциями [60, p. 455; 108, p. 207]. Было высказано мнение, что повышение частоты встречаемости ВЛГ в новейшее время может быть связано с микроэволюционными гормональными изменениями, вызванными такими достижениями цивилизации, как увеличение продолжительности жизни, свободная и легкая доступность пищи, повышение уровня метаболизма у человека и, как следствие, снижение в организме гормона лептина [104, p. 457]. Сегодня же количество палеоантропологических работ, в которых описываются случаи внутреннего лобного гиперостоза у представителей древних народов, растет с каждым годом, а география таких находок расширяется.

Самый ранний случай внутреннего гиперостоза костей свода черепа был отмечен C. Антон на черепе питекантропов Сангиран 1 (о. Ява), датирующийся 1,66-1,5 млн лет назад. Ей же были описаны аналогичные патологические состояния на черепах неандертальцев Шанидар 5 (Ирак) и Гибралтар 1 (Испания) [78, p. 116-117]. Еще один случай гиперостоза лобной кости зафиксирован на мужском черепе неандертальца Марийяк 3 (Франция), датирующийся $57600 \pm 4600$ лет до н. э. [87]. По мнению С.В. Дробышевского, появление ВЛГ у неандертальцев связано с их особым гормональным статусом, который характеризуется увеличением концентрации андрогенов - мужских гормонов. Повышение андрогенов у женщин неоантропов могло приводить к снижению их женственности и резко повышать риск выкидышей, что негативно сказывалось на размножении [23, с. 282].

Случаи лобного гиперостоза неолитического времени с территории Франции были описаны В. Девриент с соавторами. Исследова- телями изучены два женских черепа престарелого возраста, на лобной кости которых определены незначительные образования [84].

С. Флер и С. Витцель выявили ВЛГ на материалах ранней эпохи бронзы (2 700 лет до н. э.) с территории Западной Сирии, местечко Телл Мишриф, в котором располагался королевский дворец Кватна. Признаки синдрома Морганьи были обнаружены учеными на фрагментах 9 черепов. Исследователи в рамках своей работы высказали мнение о возможной корреляции внутреннего лобного гиперостоза с высоким социальным статусом индивидов [86, p. 41].

Случай лобного гиперостоза обнаружен Е.В. Перервой в процессе рентгенологического исследования деформированных черепов эпохи средней бронзы с территории Нижнего Поволжья. Находка происходит из подкурганного захоронения 10 могильника Абганерово III. Следы костных образований были найдены на черепе мужчины 25-30 лет [57, с. 14].

Целый ряд случаев внутреннего лобного гиперостоза выявлен на костных останках, найденных на территории современного Египта $[79 ; 95 ; 115]$. Группой исследователей из Каира описана патология лобной кости у мужчины 25-30 лет из погребения, датирующегося временем царствования второй династии (2890-2650 гг. до н. э.), из местечка Таркхан, находящегося на территории южного Дахшура (Египет) [107, р. 41-45]. Еще один череп со следами синдрома Морганьи, происходящий из храма Хатшепсут, расположенного на территории археологической зоны в окрестностях Луксора под названием Дейр-эль-Бахри, описали А. Бебель и А. Галиевская. Исследователи изучили мозговую капсулу женщины 20-25 лет, жившей в период XXVI династии (664-525 гг. до н. э.) [81, p. 45].

Случаи внутреннего лобного гиперостоза, датирующиеся эпохой раннего железного века скифского времени, описаны А. Козак [36], А.П. Бужиловой и М.В. Козловской [10]. У сарматов признаки ВЛГ обнаружили А.П. Бужилова [12] и М.А. Соколова [68]. Л. Тоасе [112] зафиксировала лобный гиперостоз на 4 черепах из некрополя Апулюм римского времени с территории современной Румынии, а Ф. Рюли, Т. Бёни и М. Хеннеберг [106] на кельтском мужском 
черепе из погребения 100 г. до н. э. На англосаксонских материалах из Британии ВЛГ был описан Т. Андерсоном [77], а в захоронении викингов из Норвегии патология найдена С. Муром [99].

На материалах эпохи средневековья признаки синдрома Морганьи - Сюарта - Мореля обнаружены в сериях из Венгрии [90; 98], Польши (церковь в городе Расиборз) [89], Нижней Селезии [101], Словакии (церковь Мартина) [83], на Золотоордынских материалах Нижнего Поволжья [58].

Имеется целый пласт научных трудов, демонстрирующих случаи распространения ВЛГ на территории Нового Света. Так, следует отметить работу Дж. Треллеса и М. Мендеса, которая посвящена анализу этиологии и распространению внутреннего лобного гиперостоза на территории Чили [113]. Д. Мюльхером и др. были описан целый ряд случаев у коренного населения с территории Новой Мексики [100]. Поистине фундаментальным трудом по изучению этиологии и характера распространения внутреннего лобного гиперостоза является работа группы ученых, возглавляемая И. Гершковичем. Исследователями были проанализированы массовые исторические серии Израиля и США, а также выборки белого и черного населения современной Северной Америки [92].

Материал и методика исследования. Материалом для исследования послужили черепа представителей сарматских культур из подкурганных могильников Нижнего Поволжья и Нижнего Дона. Всего было исследовано 469 черепных коробок. Из них 166 черепов относятся к черепам представителей раннесарматского времени, 144 черепа происходят из погребений среднесарматского времени и 159 черепов датируются II-IV вв. н. э. (рис. 1, табл. 1).

Степень развития лобного гиперостоза оценивалась по методике И. Гершковича и др. [92]. В своей работе исследователем были выделены четыре основных степени градации развития патологического состояния. Тип «А» характеризуется случаями развития небольших, узких костных конкреции, обычно меньше 10 мм в диаметре. Тип «В» включает случаи с узловым костным разрастанием без дискретных полей, затрагивающих менее
$25 \%$ эндокранной поверхности лобной кости. Тип «С» - более обширные узловатые костные наросты, охватывающие до 50 \% эндокранной поверхности лобной кости. Тип «D» характеризуется костными разрастаниями, затрагивающими более 50 \% внутренней поверхности лобной кости, иногда переходящими на теменные кости $[92 ; 100]$.

Описание материала. Раннесарматское время. На костных останках представителей раннесарматского времени патологические изменения на внутренней поверхности лобной кости были обнаружены на 13 черепах $(7,8 \%)$. В 9 случаях у мужчин и в 3 случаях у женщин (табл. 2). В одном случае следы изменений на лобной кости были зафиксированы у подростка 15 лет из погребения 4 кургана 4 могильника Ковалевка (раскопки 2006 г.) (рис. 2). В ряде наблюдений, когда на черепной коробке имелись следы лобного гиперостоза, определение пола у некоторых индивидов было затрудненно. Поэтому в целях уточнения половой принадлежности производился анализ сопутствующего вещевого инвентаря из погребений, что позволило практически исключить сомнения при определении гендерной принадлежности. Чаще всего внутренний лобный гиперостоз фиксировался у индивидов в возрасте «matures» - 8 наблюдений. По два случая нейроэндокринных нарушений было выявлено у молодых и старых индивидов. На черепах 11 человек степень развития лобного гиперостоза характеризуется типом «А» (см. табл. 1). На двух мозговых капсулах (у подростка из погребения 4 кургана 4 могильника Ковалевка и у женщины из погребения 3 кургана 13 могильника Маляевка V) ВЛГ имеет вторую степень развития «В» по И. Гершковичу [92].

Среднесарматское время. Частота встречаемости внутреннего лобного гиперостоза на материалах среднесарматского времени по сравнению с предыдущим сарматским периодом выше. Всего было выявлено также 13 случаев, что составило уже 9,02 \% (табл. 2). ВЛГ у средних сарматов был зафиксирован у 6 мужчин и у 7 женщин (см. табл. 1, 2). У кочевников I-II вв. н. э. данное отклонение чаще фиксируется у женщин в отличие от кочевников VI-I вв. до н. э., у которых лобный гиперостоз наблюдается преимуществен- 
но у мужчин. Картина гендерного распределения патологии лобной кости на материалах среднесарматского времени практически полностью соотносится с палеопатологическими и современными клиническими данными [92, p. 323]. В подавляющем большинстве случа- ев патология лобной кости выявляется у индивидов зрелого и престарелого возраста от 40 до 65 лет (всего 10 наблюдений). На трех черепных коробках образования зафиксированы у людей в возрасте 30-35 лет. В 7 случаях наблюдения нейроэндокриных нарушений

Таблича 1

Материал исследования

\begin{tabular}{|c|c|c|c|c|c|c|}
\hline № & Могильник & $\begin{array}{c}\text { № кургана/ } \\
\text { погребения/ } \\
\text { костяк }\end{array}$ & Пол & Возраст & $\begin{array}{c}\text { Степень } \\
\text { развития } \\
\text { патологии }\end{array}$ & Источник \\
\hline \multicolumn{7}{|c|}{ Раннесарматское время (IV-I вв. до н. э.) } \\
\hline 1 & Бахтияровка II, 1986 & $33 / 6$ & M & $35-45$ & $\mathrm{~A}$ & [39] \\
\hline 2 & Большая Ивановка, 1992 & $1 / 1$ & M & $60-65$ & A & {$[66$, c. 58$]$} \\
\hline 3 & Ковалевка, 2006 & $1 / 10$ & ж & $25-30$ & $\mathrm{~A}$ & [52] \\
\hline 4 & Ковалевка, 2006 & $1 / 12$ & M & $30-40$ & A & [52] \\
\hline 5 & Ковалевка, 2006 & $3 / 4$ & M & $60-70$ & $\mathrm{~A}$ & [52] \\
\hline 6 & Ковалевка, 2016 & $10 / 1$ & ж & $40-50$ & A & [26] \\
\hline 7 & Ковалевка, 2006 & $4 / 4 / 2$ & подр & 15 & B & [51] \\
\hline 8 & Лятошинка, 1990 & $1 / 2$ & $M$ & $25-30$ & $\mathrm{~A}$ & [27] \\
\hline 9 & Маляевка V, 1998 & $13 / 3$ & ж & $35-45$ & $\mathrm{~B}$ & [65] \\
\hline 10 & Моисеево, 2014 & $3 / 2$ & M & $35-45$ & A & {$[13]$} \\
\hline 11 & Новый & $20 / 5$ & $\mathrm{M}$ & $35-40$ & $\mathrm{~A}$ & [30] \\
\hline 12 & Перегрузное I, 2000 & $13 / 15$ & M & $35-45$ & $\mathrm{~A}$ & [33] \\
\hline 13 & Царев, 1990 & $83 / 5$ & M & $35-45$ & $\mathrm{~A}$ & [51] \\
\hline \multicolumn{7}{|c|}{ Среднесарматское время (I-II вв. н. э.) } \\
\hline 1 & Кондраши, 2002 & $2 / 1$ & $M$ & $40-45$ & $\mathrm{D}$ & [48] \\
\hline 2 & Лебяжье, 1992 & $13 / 2$ & ж & $55-60$ & $\mathrm{~B}$ & [66] \\
\hline 3 & Новый & $130 / 11$ & ж & $40-50$ & $\mathrm{~B}$ & [30] \\
\hline 4 & Новый & $63 / 1$ & M & $35-40$ & $\mathrm{~A}$ & [30] \\
\hline 5 & Ольховка I, 2003 & $1 / 1$ & ж & $25-30$ & $\mathrm{~A}$ & [67] \\
\hline 6 & Первомайский VII, 1984 & $42 / 4$ & $M$ & $40-45$ & $\mathrm{D}$ & [47] \\
\hline 7 & Первомайский I, 1985 & $13 / 2$ & ж & $55-60$ & $\mathrm{~A}$ & {$[20$, c. $187-188]$} \\
\hline 8 & Перегрузное I, 2001 & $16 / 1 / 2$ & ж & $60-65$ & $\mathrm{D}$ & {$[34]$} \\
\hline 9 & Перегрузное I, 2010 & $45 / 3$ & ж & $25-35$ & $\mathrm{~A}$ & {$[35]$} \\
\hline 10 & Рыбинка, 2014 & $1 / 1$ & $M$ & $35-45$ & $\mathrm{~A}$ & [13] \\
\hline 11 & Сладковка, 1978 & $14 / 1$ & $M$ & $30-35$ & B & [44] \\
\hline 12 & Сладковка, 1983 & $23 / 1$ & $\mathrm{M}$ & $25-30$ & $\mathrm{~A}$ & [45] \\
\hline 13 & Сохранный, 2015 & $1 / 2$ & ж & $60-65$ & $\mathrm{~A}$ & [62] \\
\hline \multicolumn{7}{|c|}{ Позднесарматское время (II-IV вв. н. э.) } \\
\hline 1 & Абганерово II & $4 / 1$ & M & $50-60$ & A & [24] \\
\hline 2 & Аксай-2, 2006 & $1 / 1$ & M & $45-50$ & $\mathrm{~A}$ & [25] \\
\hline 3 & Аксай-2, 2006 & $5 / 1$ & M & $50-55$ & A & [25] \\
\hline 4 & Аксай-2, 2006 & $35 / 1$ & $\mathrm{M}$ & $20-25$ & $\mathrm{~A}$ & {$[25]$} \\
\hline 5 & Аксай-4 & $3 / 1$ & $M$ & $40-50$ & $\mathrm{~B}$ & [35] \\
\hline 6 & Аксай-5 & $1 / 2$ & M & $35-40$ & $\mathrm{~A}$ & [35] \\
\hline 7 & Заря I & $1 / 1$ & M & $30-40$ & $\mathrm{~B}$ & [38] \\
\hline 8 & Лятошинка, 1990 & $2 / 2$ & M & $20-25$ & $\mathrm{~A}$ & [27] \\
\hline 9 & Новый Рогачик, 1978 & $10 / 1$ & M & $25-30$ & $\mathrm{~A}$ & [46] \\
\hline
\end{tabular}

Таблииа 2

Характер распространения внутреннего лобного гиперостоза у сарматов

\begin{tabular}{|l|c|c|c|c|c|c|c|c|c|}
\hline \multirow{2}{*}{ Сарматская серия } & \multicolumn{3}{|c|}{ Суммарная серия } & \multicolumn{3}{|c|}{ Мужчины } & \multicolumn{3}{|c|}{ Женщины } \\
\cline { 2 - 11 } & $S$ & $n$ & $\%$ & $S$ & $n$ & $\%$ & $S$ & $n$ & $\%$ \\
\hline Ранние сарматы & 166 & 13 & 7,8 & 94 & 9 & 9,6 & 71 & 3 & 4,2 \\
\hline Средние сарматы & 144 & 13 & 9,03 & 81 & 6 & 7,4 & 63 & 7 & 11,1 \\
\hline Поздние сарматы & 159 & 9 & 5,7 & 119 & 9 & 7,6 & 38 & 0 & 0 \\
\hline Всего & 469 & 35 & 7,5 & 291 & 24 & 8,2 & 177 & 10 & 5,6 \\
\hline
\end{tabular}


на лобной кости степень проявления патологии характеризуется типом «А» (небольшая, изолированная, выделяющаяся область не более 10 мм в диаметре на передней части кости, на одной стороне или по обеим сторонам от лобного синуса). Три случая типа «В» и 3 наблюдения типа «D» [92, p. 307-308].

Позднесарматское время. На материалах II-IV вв. н. э. было зафиксировано 9 случаев внутреннего лобного гиперостоза. Все наблюдения были выявлены на черепах мужчин. В 6 случаях мозговые капсулы носят на себе следы преднамеренной искусственной деформации. Оценка возрастных зависимостей развития лобного гиперостоза на материалах позднесарматской культуры позволила выяснить, что данная патология в одинаковой мере характерна как для молодых (4 случая), так и для возрастных индивидов старше 35 лет (5 случаев) (табл. 3 ). В процентном соотношении на материалах позднесарматского времени ВЛГ встречается реже, чем в других сарматских сериях (см. табл. 2). В то же время обращает на себя внимание то обстоятельство, что в серии II-IV вв. н. э. случаев лобного гиперостоза на женских черепах не обнаружено. Данное наблюдение не соответствует современным представлениям о распространении внутреннего лобного гиперостоза. Если характеризовать степень развития патологических состояний на лобной кости, то в 7 случаях выявлен тип «А» и только 2 раза тип «В».

Обсуждение. Одним из интереснейших аспектов в палеопатологии носителей сарматских культур является систематичная встречаемость на их мозговых коробках такой патологии, как внутренний лобный гиперостоз.

Чаще всего данная патология наблюдается в среднесарматской выборке $(9,02 \%)$. Причем в это время данное отклонение преобладает у женщин $(11,1 \%)$, что не противоречит клиническим и палеопатологическим данным. У ранних сарматов частота встречаемости ниже $(7,8 \%)$, и признак в два раза чаще встречается у мужчин $(9,6 \%)$, чем у женщин (4,2 \%). У поздних сарматов данная патология отмечается реже $(5,7 \%)$. Зафиксировано 9 случаев, и все у мужчин $(7,7 \%)$. В генеральной же выборке частота встречаемости лобного гиперостоза у взрослого населения Нижнего Поволжья и Нижнего Дона
IV в. до н. э. - IV в. н. э. достигает показателя 7,5\% (см. табл. 2), что в целом выше, чем в большинстве исторических серий (рис. 3).

Характер развития ВЛГ у сарматов в подавляющем большинстве случаев ограничивается слабой степенью (так называемый тип «А»). Вариант «В» по И. Гершковичу [92], или тип «Мinor» по X. Май [97], был выявлен во всех разновременных сарматских группах (рис. 4). Самая сильная степень проявления внутреннего лобного гиперостоза «D», или «moderate», зафиксирована исключительно на материалах среднесарматского времени (Кондраши, 2002, к. 2, п. 1; Первомайский VII, к. 42, п. 4 (рис. 5); Перегрузное I, к. 16, п. 1, к. 2).

В результате анализа частот распространения внутреннего лобного гиперостоза в суммарной сарматской серии представление исследователей о возрастной зависимости данного патологического состояния в целом подтверждается. Из 35 случаев наблюдения синдрома Морганьи - Стюарта - Мореля 17 (48,6 \%) были выявлены у взрослых индивидов в возрасте от 35 до 55 лет, а 8 наблюдений $(22,9 \%)$ были сделаны на материалах, принадлежащих людям престарелого возраста старше 55 лет (табл. 3).

Таблииа 3

\section{Возрастные показатели встречаемости} ВЛГ

\begin{tabular}{|l|c|c|c|c|}
\hline \multirow{2}{*}{ Сарматская серия } & \multicolumn{4}{|c|}{ Возраст } \\
\cline { 2 - 5 } & Uvenis & Adultus & Maturus & Senilis \\
\hline Ранние сарматы & 1 & 2 & 8 & 2 \\
\hline Средние сарматы & 0 & 3 & 6 & 4 \\
\hline Поздние сарматы & 0 & 4 & 3 & 2 \\
\hline
\end{tabular}

Был выявлен один случай развития патологии лобной кости у индивида в подростковом возрасте. Так, на раннесарматском черепе из погребения 4 кургана 4 могильника Ковалевка были обнаружены симметричные новообразования на внутренней пластине лобной кости, которые по характеру развития могут быть отнесены к типу «В» по И. Гершковичу [92]. Из сопутствующих патологических состояний на черепной коробке индивида зафиксированы следы поротического гиперостоза глазниц и свода черепа, что может указывать на развитие симптомов железодефицитной анемии в детском возрасте. Кроме этого, на костях лицевого отдела черепа и на 
костях свода черепа обнаружены признаки разреженности костной ткани, указывающие на развитие хронической формы витаминной недостаточности.

На самом деле, случай фиксации внутреннего лобного гиперостоза на черепной коробке подростка достаточно неординарная вещь. Тем не менее в современной клинической практике наблюдения раннего формирования синдрома Морганьи - Стюарта - Мореля в научной литературе описаны. Так, М.Ф. Исмагилов, Д.Р. Хасанова и др., ссылаясь на работу Б. Бахур, А.М. Бондарь, А.А Чеклед и Г.К. Стародубцева, указывают на случай внутреннего лобного гиперостоза у ребенка 11-летнего возраста [31]. Н.Ф. Докучаева и др. зафиксировали 4 случая заболевания в юношеском возрасте у больных женского и мужского пола [22, с. 22]. М. Яксионг и др. описали случай внутреннего лобного гиперостоза у семилетнего мальчика из Китая. Врачи сделали предположение о возможной корреляции развития патологии лобной кости с травмой черепа и головного мозга, которая была получена в двухлетнем возрасте [117, р. 4].

Теперь постараемся ответить на вопрос о причинах распространения внутреннего лобного гиперостоза у сарматских кочевников Нижнего Поволжья и Нижнего Дона.

О возможной взаимосвязи развития синдрома Морганьи - Стюарта - Мореля из-за механических повреждений (черепно-мозговые травмы) уже высказывалось мнение в научной литературе. В то же время, несмотря на то, что исследователями указывалось, что сарматы вели достаточно агрессивный образ жизни [4; $8 ; 55]$, случаев травм костей свода черепа в исследованной серии кочевников с ВЛГ сравнительно мало, всего лишь три наблюдения.

Дополнительно отметим, что в последний сарматский период на 6 черепах с ВЛГ зафиксированы следы преднамеренной искусственной деформации. Вообще, воздействию деформирующей конструкции, которую применяли древние народы для модификации своей головы, на развитие патологических признаков на черепе исследователи также уделяли особое внимание. Так, М.А. Балабанова и А.В. Сычева описали случай лобного гиперостоза на черепе мужчины пожилого возраста, относящегося к позднесарматскому времени, из кур- ганного могильника Абганерово II [3, с. 159]. Кроме этого, ученые, осуществив рентгенологическое изучение деформированных черепов поздних сарматов Нижнего Поволжья, пришли к заключению, что на некоторых из них имеются изменения в области турецкого седла. По мнению исследователей, данные наблюдения могут указывать на существование высокой степени вероятности развития гормональных нарушений в организме людей с деформаций головы, что могло повлиять на психическое модифицирование полового поведения индивидов [2;12].

Сходной точки зрения придерживаются и авторы данной работы, так как аналогичные тенденции были выявлены в результате рентгенологического исследования серий деформированных черепов эпохи средней бронзы и позднего средневековья. Так, следы лобного гиперостоза были обнаружены на деформированном черепе мужчины катакомбной культуры из могильника Абганерово III [57]. На материалах золотоордынского времени у мужчины $35-$ 45 лет с затылочной деформацией черепа из погребения 2 кургана 80 могильника Царев был выявлен гиперостоз внутренней пластины лобной кости $[58$, с. 110$]$.

Что же касается суммарной серии сарматов, то считать преднамеренную искусственную деформацию черепа и черепно-мозговые травмы основной причиной развития внутреннего лобного гиперостоза неперспективно, так как признаков деформации у носителей ранне- и среднесарматской культуры не зафиксировано, а травмы свода черепа редки, и частота встречаемости патологии лобной кости в ранних сарматских группах выше. В то же время отказываться от идеи, что преднамеренное и непреднамеренное воздействие на черепно-мозговой отдел может быть стимулом к развитию патологических отклонений, преждевременно. Необходимо проведение дальнейших исследований, накопление сравнительных и эмпирических данных.

Еще одной причиной, по которой внутренний лобный гиперостоз достаточно часто фиксируется в сарматских группах, может быть генетическая предрасположенность.

О вероятной наследственной зависимости проявления синдрома Морганьи - Стюарта - Мореля уже писалось [12; 69; 73]. 
Так, внутренний лобный гиперостоз был зафиксирован у скифов - народа, близкого сарматам по происхождению и образу жизни. На территории Украины А. Козак выявила случай синдрома Морганьи у зрелой женщины из погребения 2 кургана 19 могильника Перещепенский [36, с. 60].

А.П. Бужилова и М.В. Козловская зафиксировали 6 случаев лобного гиперостоза среди 32 взрослых индивидов из серии могильника Терновое I и Колбино I, относящихся к скифскому времени. Частота встречаемости патологии внутренней пластины лобной кости в данной выборке достигает $18 \%$, что значительно выше общемировых показателей даже в настоящее время [10].

М.А. Соколовой и А.П. Бужиловой при исследовании серии сарматов, состоящей из 125 черепных коробок взрослых индивидов, также было выявлено 6 случаев синдрома Морганьи - Стюарта - Мореля [12, с. 205; 68, с. 189].

Несмотря на то обстоятельство, что у сарматского населения Юга России отмечается широкий диапазон изменчивости, объясняющий сложный и неодинаковый процесс этногенеза различных сарматских групп [56, c. 25-26; 76, с. 38-39], многие исследователи указывали на схожесть в антропологическом плане сарматских серий с различных территорий. Так, Т.С. Кондукторова в результате изучения сарматских серий с Украины высказала мнение, что у них наблюдается антропологический тип, находящий аналогии у сарматов Нижнего Поволжья [37, с. 172-173]. С.И. Круц, приводя сводку накопившего к началу 90-х гг. ХХ в. костного материала из могильников Таврии, указала на их сходство с остальным сарматским миром [40].

На близость сарматов Западного Казахстана к кочевникам Поволжья и Приуралья указывали В.В. Гинзбург и Б.В. Фирштейн [16, с. 406-407]. В.В. Гинзбург высказал мнение о существовании унифицированного антропологического типа сарматов, с незначительными локальными особенностями [17, с. $575 ; 88$, p. 308-310]. О близости антропологического типа сарматов Маныч-Сальского междуречья говорила Е.Ф. Батиева [8].

О сходстве в морфологическом плане сарматов раннего и среднего этапов в своих работах писали Б.В. Фирштейн и М.А. Бала- банова [1; 72]. На несомненную связь сарматов с предшествующими скифскими и савроматскими племенами в генетическом плане указывала М.А. Балабанова [1] и А.П. Бужилова и др. [12].

Исследование частот встречаемости эпигенетических признаков в сарматской серии показало, что у всех сарматов широко распространены различные аномалии черепа и зубочелюстной системы. Наивысшие частоты из дискретно-варьирующих признаков имеют такие аномалии, как дополнительные косточки в затылочном шве черепа, пальцевидные вдавления, метопический (лобный) шов. Причем одни и те же показатели характерны и для суммарных, и для локальных разновременных сарматских групп. Выявленная картина распространения этих фенов в сарматских группах заставляет обратиться к гипотезе, высказанной отечественными антропологами, о существовании морфологического начала, которое объединяет всех сарматов между собой [56].

В связи со всем выше изложенным вполне вероятно, что появление синдрома Морганьи - Стюарта-Мореля в разновременных сарматских сериях может быть связано с генетической предрасположенностью, которая запускалась специфическим активаторами.

В случае с сарматскими женщинами и мужчинами такими стимуляторами могли выступить образ жизни и характер питания.

Практически во всех письменных источниках скифов, савроматов и их возможных потомков сарматов определяют как кочевников $[6$, с. $13 ; 50$, с. 3$]$. Что же касается образа жизни, то описание его походного и кочевого уклада мы находим у таких авторов античности, как Помпоний Мела [61], Страбона [70], Тацита [71], Эннодия [42, с. 304], Аммиана Марцелина [49].

Достаточно специфично в письменных источниках дается характеристика внешнего облика, поведения и рода занятий скифских и сарматских женщин. Гиппократ пишет следующее о внешнем облике скифов: «...по внешнему виду скифы толсты, мясисты, нерасчленены, влажны и слабы. Вследствие тучности и гладкости тела по внешнему виду все похожи друг на друга» [18, с. 299]. Также древний врач отмечает слабую плодовитость скиф- 
ских мужчин и женщин, связывая это у первых с верховой ездой, а у вторых с «ожирением и влажностью» [18, с. 299].

Геродот указывает «савроматские женщины исстари ведут свой образ жизни: они ездят верхом на охоту с мужьями и без них, выходят на войну и носят одинаковую с мужчинами одежду» $[15$, кн. IV, 116 , с. 200]. Относительно браков соблюдается следующее правило: ни одна девушка не выходит замуж, пока не убьет врага; некоторые из них и умирают в старости безбрачными, потому что не могли выполнить этого требования [15, кн. IV, 117 , с. 200]. Помпоний Мела так описывает сарматов: «Даже женщины участвуют в войне наравне с мужчинами» [61, кн. III, IV, 29, c. 225]. Также Помпоний Мела упоминает о том, что сарматские девочки-подростки были «обязаны упражняться в стрельбе из луков, верховой езде и охоте» [61, кн. I, XIX, с. 227]. У Полиена имеются упоминания о сарматской царице Амаге, напавшей с конным отрядом сарматов на царскую ставку скифов [60, с. 284-285]. Флавий Вописк сообщает о 10 сарматских женщинах, взятых в плен императором Аврелианом (70-е гг. III в.), которые в мужской одежде сражались среди готов [73].

Характеристика сарматских женщин в античных письменных источниках, а также подтверждение этих сведений археологическими находками вооружения в женских погребениях позволяют нам сделать предположение, что ведение ими походного образа жизни наравне с мужчинами, возможно, приводило к матуризация сарматок, снижению эстрогенов в организме, нарушению полового поведения и функции воспроизводства. А.П. Бужилова указывает, что сдвиги в соотношении «эстрадиол / тестостерон» происходят при нарушении полового поведения и смене социальной роли, что и происходило в некоторых случаях с женщинами в сарматском обществе [12]. Исследование группы ученых, возглавляемых И. Гершковичем, показало, что женщины, занимающие лидерские позиции, мало или не рождающие детей, а также отказывающиеся от грудного вскармливания, чаще подвержены развитию эндокринных нарушений, нежели женщины, проводящие большую часть репродуктивного возраста вынашивая ребенка [92].
Таким образом, ведение мужского образа жизни, продолжительное времянахождение в походах, участие в военных столкновениях могли приводить к развитию в женском организме эндокринных нарушений.

Теперь необходимо также ответить на вопрос: по какой причине наблюдается гендерный крен в проявлении ВЛГ у сарматов?

Как и в случае с женщинами сарматского времени, на мужчин, вероятнее всего, действовал тот же набор факторов, обусловленных процессами адаптации к образу жизни (генетические, механические, гастрономические).

Так, к развитию гормональных нарушений могло приводить длительное нахождение сарматов в седле. Древнегреческий врач Гиппократ вот так высказывался по поводу скифов: «Постоянные толчки при верховой езде приводят у них к половому бессилию» [18, c. 298-300]. О том, что савроматы и сарматы как истинные номады долгое время проводят на коне, говорится в работах античных авторов. Римский историк Тацит указывает, что сарматы - это народ, «проводящий всю жизнь на повозке и на коне» [71, с. 356]. Плиний Старший дает описание сарматов, находящихся в походе: «Таким образом, они, сидя верхом, продвигаются непрерывно на расстояние сто пятьдесят миль» [59, кн. III, IV, c. 225]. Сидоний Апполинарий указывает: «Дети с раннего возраста приучаются скакать на коне» [69, с. 288]. Аммиан Марцеллин писал об аланах: «Молодежь с раннего детства, сроднившись с верховой ездой, считает позором для мужчины ходить пешком»; «сарматы объезжают обширные пространства... они ведут по одному, а иногда по два коня», что позволяло им проходить на конях до 200 км в день [49, кн. XXXI, 2, 20, с. 493]. А.П. Бужилова, ссылаясь на современные исследования, посвященные велосипедистам, высказала предположение, что в результате длительного нахождения в седле у сарматских мужчин могло происходить нарушение кровообращения в области гениталий, что негативно влияло на выработку тестостерона, а также стимулировало развитие половых болезней и возникновение синдрома Морганьи - Стюарта Мореля [12, с. 211].

Малоподвижный (сидячий) образ жизни сарматских мужчин и женщин отягощался 
специфическим пищевым поведением, которое можно назвать традиционным для кочевников раннего железного века и которое практически не менялось на протяжении всей сарматской истории.

Кочевой и скотоводческий уклад сарматов обусловил и их систему питания. Страбон сравнивает сарматов с галактофагами (млекоедами) [70, с. 296]. Питались сарматы преимущественно продуктами животного происхождения, редко просяной кашей $[5$, с. $8 ; 50$, c. 8]. Подтверждение того, что сарматы в основном употребляли в пищу мясо, кобылье молоко, кровь животных, сыр, кисломолочные продукты, а также диких животных, мы находим в работах Клавдия Элиана, Плиния Старшего [32; 59]. Марк Аврелий Марциал (I в. н. э.) в своей книге эпиграмм пишет: «...пришел сармат, сытый кровью коня» [41, № 3, с. 219]. Климент Александрийский (IIIв. н. э.) вот что указывает о скифах: «...скиф несется куда хочет, мучимый голодом, он требует пищи у коня, последний предоставляет ему свои жилы и отдает господину все, что имеет - кровь; таким образом, конь для кочевника является средством передвижения и пищей» [41, № 2, c. 281].

Этнографические исследования особенностей питания кочевников Центральной Азии указывают, что свежее мясо скифы, монголы, тибетцы, казахи употребляли в пищу в основном осенью, а кровь (так называемая живая кровь) животных употребляли достаточно часто, особенно в походах или в голодные периоды [29]. В этнографии кочевых народов описывается, что в периоды голода в пищу шли не только мясо, внутренности и кровь животных, ели также копыта и кости [9, с. 9]. Кроме этого, в голодоморы в пищу употребляли и падаль, то есть животных, издохших от голода или болезней, что отмечали у кочевников в разные исторические периоды: у скифов - в V в. до н. э.; у монголов - в XIII в. н. э.; у крымских татар в XVI-XVII вв.; у калмыков - даже в XIX в. $[28 ; 53 ; 64 ; 74]$.

Н.Л. Жуковская, описывая особенности питания кочевников Центральной Азии (монголов, уйгуров, тибетцев, казахов, киргизов) конца XIX - начала XX в., указывает, что в летний период кочевники в основном употребляли молочную пищу, а в зимний - мясную $[29$, c. $65-66]$.
Археологические исследования указывают на то, что в раннесарматское время в подавляющем большинстве погребений заупокойная пища представлена в виде костных останков туши барана, реже - крупного рогатого скота и лошади. Определения содержания соединений фосфора из придонной части грунта из погребальных сосудов свидетельствуют о наличии в горшках сарматских погребений молока и мясного бульона [21].

Кроме того, что диета кочевников базировалась в основном на мясо-молочной составляющей, то есть была очень далека от сбалансированного рациона, имеются свидетельства в античных источниках и о том, что питались они несистематично. Помня о периодах голодания, савромат-сармат «наедался через каждые три дня до пресыщения» [32].

Таким образом, свидетельства античных источников, данные этнографии и археологии позволяют нам сделать предположение о том, что как для сарматских мужчин, так и для женщин была характерна несбалансированная диета с высоким содержанием жиров и белков, к тому же питание было несистематичным. Длительные периоды голода чередовались с моментами, когда кочевники предавались перееданию. Такой рацион, вполне вероятно, провоцировал у кочевого населения Нижнего Поволжья раннего железного века развитие различных системных нарушений.

Так, например, отсутствие в рационе свежих продуктов могло приводить к различным авитаминозам, которые выявлены у неполовозрелого населения сарматских культур, а также к развитию недостатка йода и, как следствие, нарушению работы щитовидной железы. Голодовки и периоды перенасыщения едой, а также пища обогащенная жирами могли стимулировать нарушения работы поджелудочной железы, которая отвечает за выработку инсулина, приводя к развитию сахарного диабета и, как следствие, ожирению. Так, А.П. Бужилова и И.С. Каменецкий приводят описания изменений на костных останках позднего сармата с признаками приобретенного диабета [11].

Таким образом, специфический образ жизни (походный, кочевой), диета (большое содержание белков и жиров) и несистематичное питание (периоды голода чередовались с 
Е.В. Перерва, В.И. Моисеев. Внутренний лобный гиперостоз на костных останках сарматов

перееданием про запас), характерные для кочевников раннего железного века, вероятнее всего, явились определяющими факторами, стимулирующими развития маркеров эндокринных нарушений.

Заключение. Зафиксированные частоты встречаемости внутреннего лобного гиперостоза свидетельствуют о существовании у сарматов системных заболеваний эндокринной системы.

Синдром Морганьи - Стюарта - Мореля на кочевнических материалах IV в. до н. э. IV в. н. э. не обнаруживает гендерной направленности современного типа.

Существуют возрастные зависимости в проявлении патологии, но обнаруженные случаи встречаемости ВЛГ у подросткового и молодого населения указывают на формирование серьезных эндокринных нарушений уже в раннем возрасте.

Запуск развития внутреннего лобного гиперостоза (синдрома Морганьи - Стюарта Мореля) у сарматов связан: торами;

- с генетически обусловленными фак-

- специфической диетой, которая стимулирует нарушение обмена веществ;

- специфическим образом жизни («кочевой, походный»), который был характерен для женщин и для мужчин как наиболее активной части сарматского населения;

- длительным нахождением в конском седле;
- психоэмоциональными нагрузками следствие агрессивного поведения (длительные войны, походы, защита территорий, кочевий).

\section{СПИСОК СОКРАЩЕНИЙ}

ВОКМ - Волгоградский областной краеведческий музей.

ВОНПЦ - Волгоградский областной научнопроизводственный центр по охране памятников истории и культуры.

ВДИ-Вестник древней истории.

МИА - Материалы и исследования по археологии СССР.

$H A B$ - Нижневолжский археологический вестник.

СМАЭ - Сборник Музея антопологии и этнографии.

ТИЭ - Труды Института этнографии им. Н.Н. Миклухо-Маклая АН СССР.

\section{ПРИМЕЧАНИЕ}

${ }^{1}$ Статья выполнена в рамках государственного задания Министерства образования и науки РФ, проект № 33.2830.2017/4.6 «Юг России в эпоху раннего железного века: диалог культур Восток Запад».

Хотелось бы выразить огромную благодарность директору НИИ и музея антропологии МГУ им. М.В. Ломоносова, доктору исторических наук, академику РАН Александре Петровне Бужиловой за научные консультации при подготовке данной работы. 
ПРИЛОЖЕНИЕ

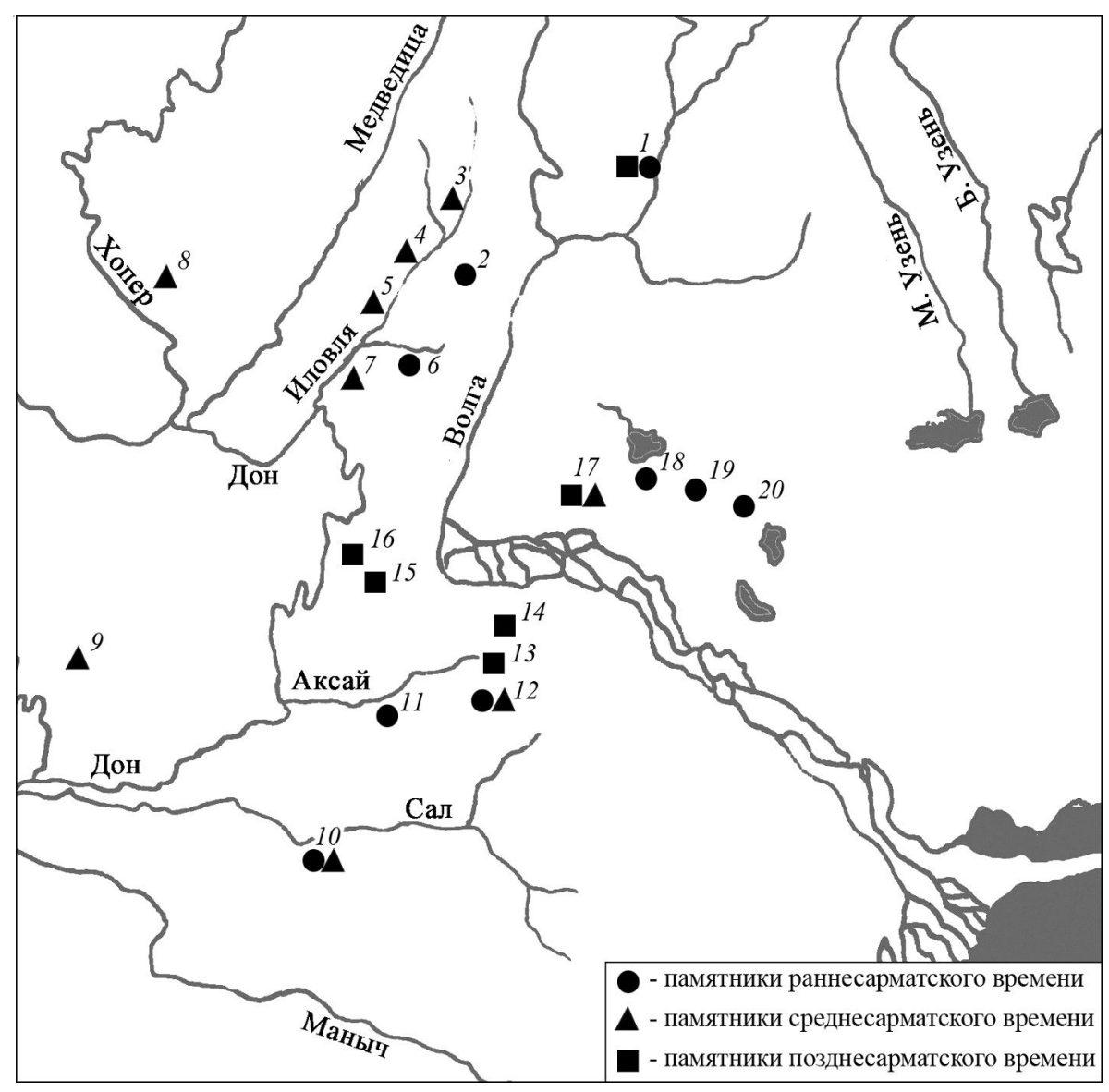

Рис. 1. Карта расположения памятников сарматского времени, в которых были найдены черепа с внутренним лобным гиперостозом:

1 - Лятошинка; 2 - Моисеево; 3 - Лебяжье; 4 - Рыбинка; 5 - Ольховка; 6 - Большая Ивановка; 7 - Кондраши;

8 - Сохранный; 9 - Сладковка; 10 - Новый; 11 - Ковалевка; 12 - Перегрузное; 13 - Аксай; 14 - Абганерово; 15 - Заря; 16 - Новый Рогачик; 17 - Первомайский; 18 - Бахтияровка; 19 - Маляевка; 20 - Царев

Fig. 1. The map of burial sites of the Sarmatian time where skulls with hyperostosis frontalis interna were found:

1 - Lyatoshinka; 2 - Moiseevo; 3 - Lebyazhye; 4 - Rybinka; 5 - Olkhovka; 6 - Bolshaya Ivanovka; 7 - Kondrashi; 8 - Sokhrannyy; 9 - Sladkovka; 10 - Novyy; 11 - Kovalevka; 12 - Peregruznoe; 13 - Aksai; 14 - Abganerovo; 15 - Zarya; 16 - Novyy Rogachik; 17 - Pervomayskiy; 18 - Bakhtiyarovka; 19 - Malyaevka; 20 - Tsarev 
Е.В. Перерва, В.И. Моисеев. Внутренний лобный гиперостоз на костных останках сарматов

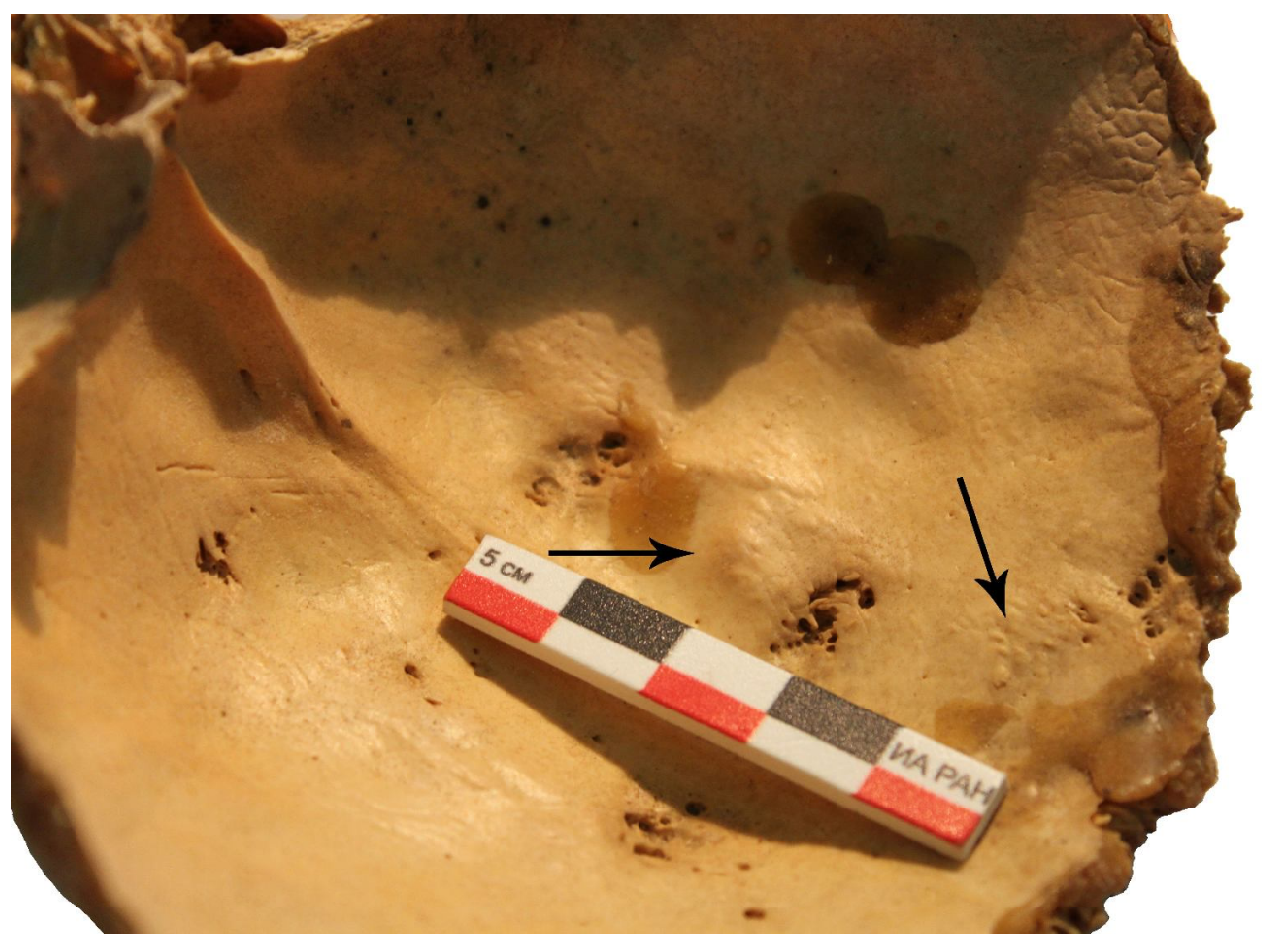

Рис. 2. Внутренний лобный гиперостоз у подростка из погребения 4 кургана 4 могильника Ковалевка (раннесарматское время)

Fig. 2. Hyperostosis frontalis interna in a teenager from burial 4, barrow 4, the Kovalevka burial mound (Early Sarmatian time)

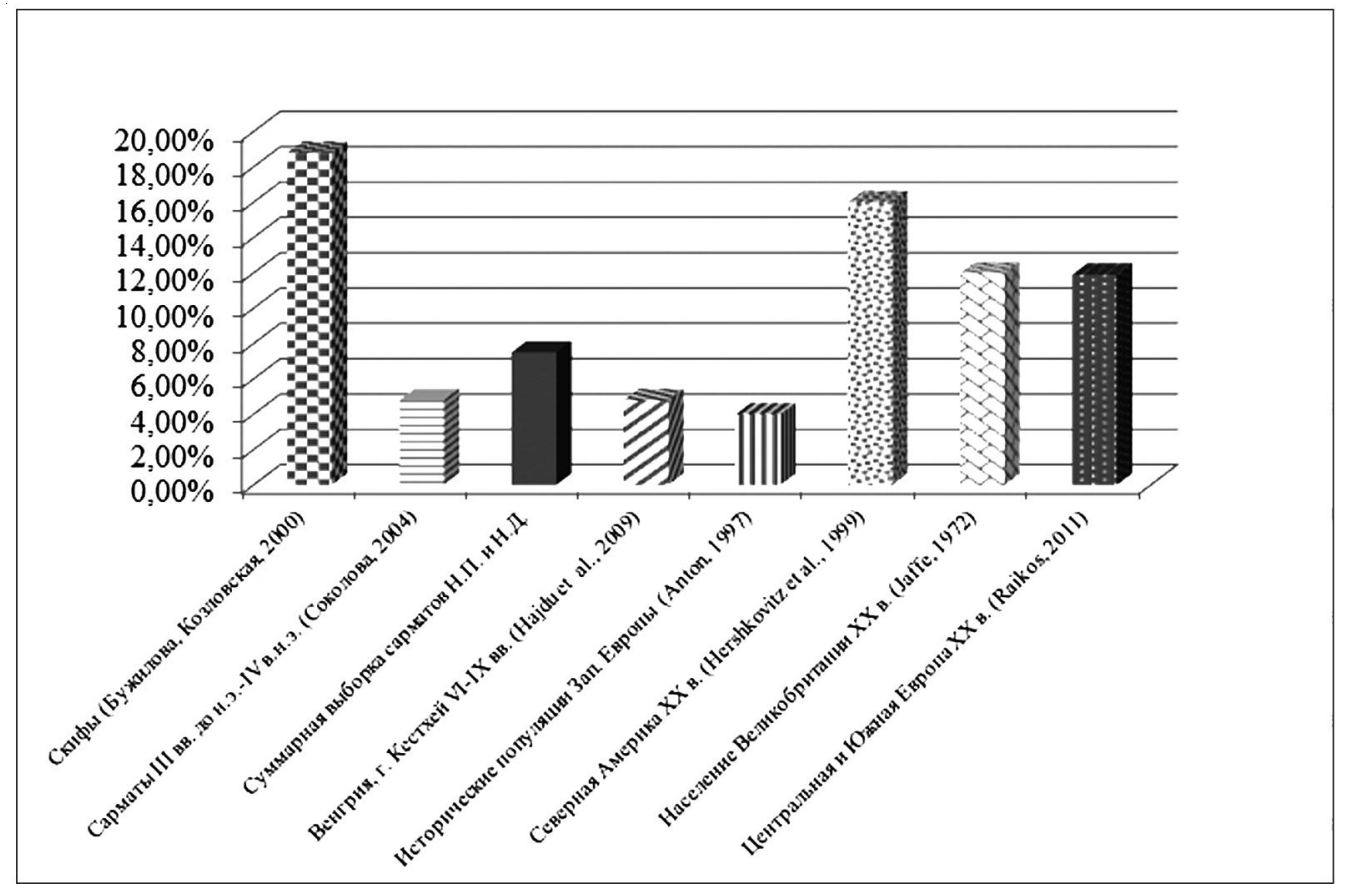

Рис. 3. Частоты встречаемости синдрома Морганьи - Стюарта - Мореля в исторических сериях и в группах XX века

Fig. 3. Frequency of occurrence of Morgagni-Stewart-Morel syndrome in historical series and in groups of the $20^{\text {th }}$ century 


\section{АРХЕОЛОГИЯ}

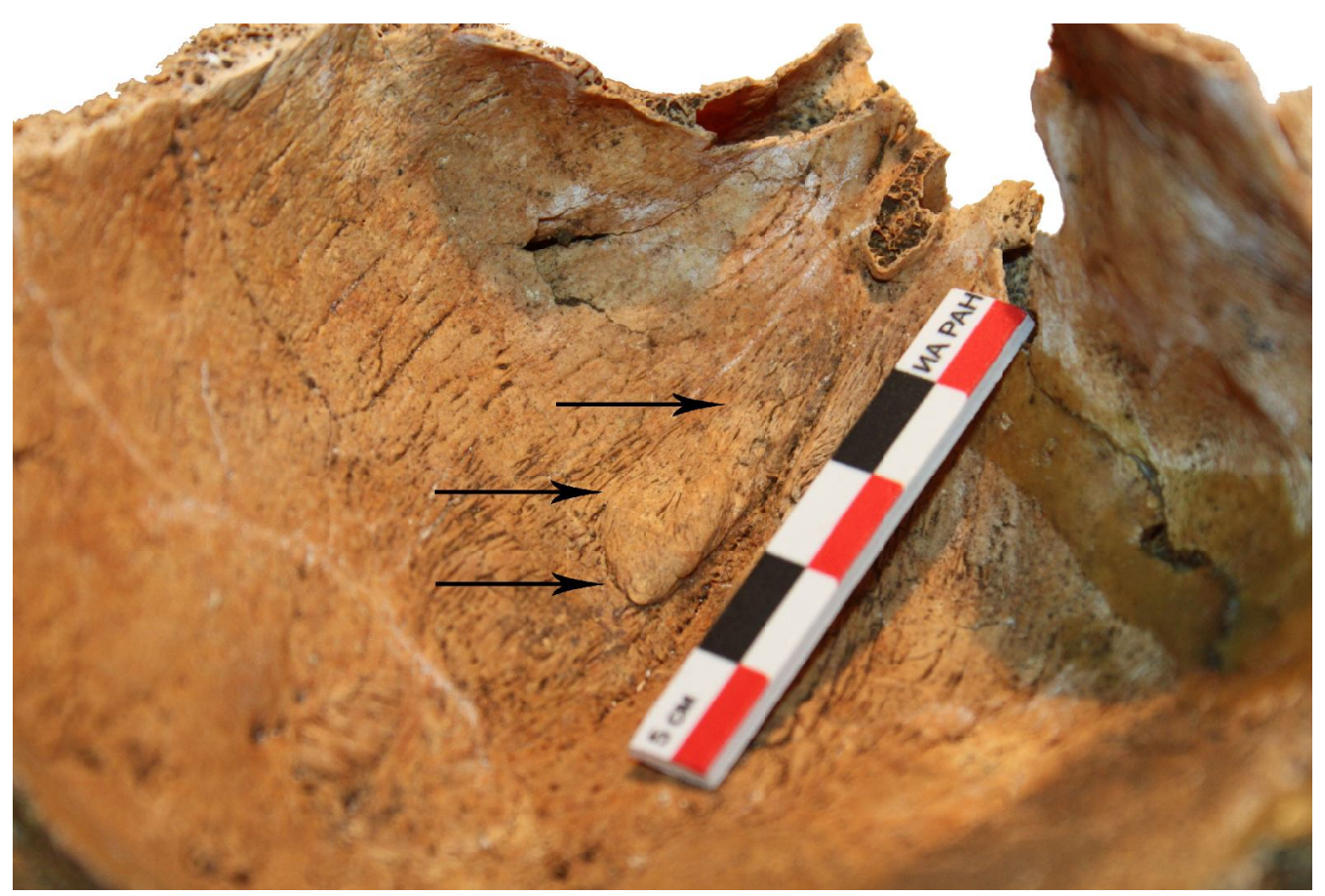

Рис. 4. Внутренний лобный гиперостоз по типу «В» у женщины 55-60 лет из погребения 2 кургана 13 могильника Лебяжье (среднесарматское время)

Fig. 4. Hyperostosis frontalis interna of type B in a 55-60 year-old woman from burial 2, barrow 13, the Lebyazhye burial mound (Middle Sarmatian time)

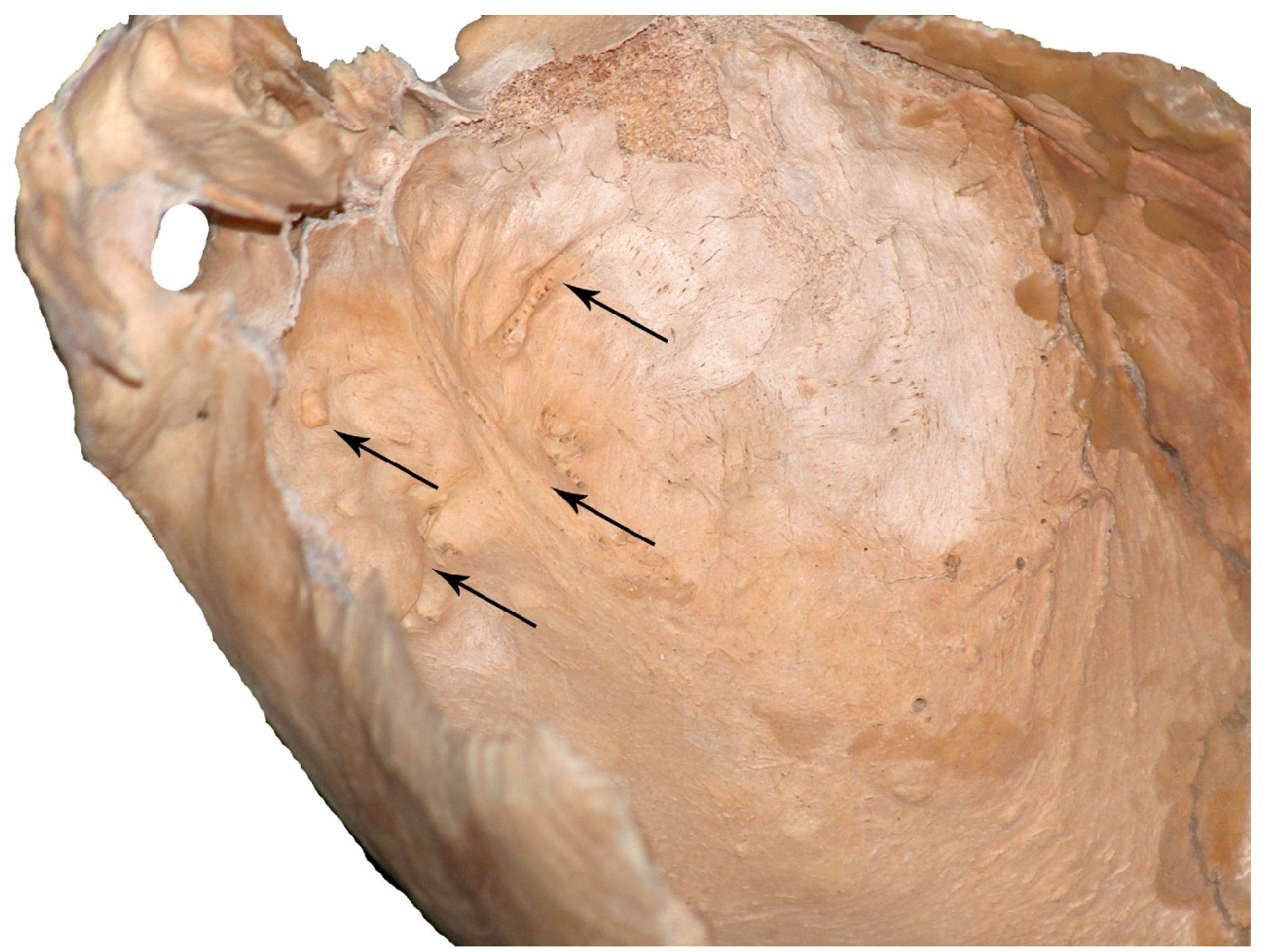

Рис. 5. Признаки внутреннего лобного гиперостоза по типу «D» у мужчины $40-45$ лет из погребения 4 кургана 42 могильника Первомайский VII (среднесарматское время)

Fig. 5. Hyperostosis frontalis interna of type $\mathrm{D}$ in a 40-45 year-old man from burial 4, barrow 42, the Pervomayskiy VII burial mound (Middle Sarmatian time) 


\section{СПИСОК ЛИТЕРАТУРЫ}

1. Балабанова, М. А. Антропология древнего населения Южного Приуралья и Нижнего Поволжья. Ранний железный век / М. А. Балабанова. М. : Наука, 2000. - 133 с.

2. Балабанова, М. А. О древних макрокефалах Восточной Европы / M. А. Балабанова // OPUS: Междисциплинарные исследования в археологии. М. : ИА РАН, 2004. - Вып. 3. - С. 171-187.

3. Балабанова, М. А. Рентгенологическое исследование позднесарматских черепов / М. А. Балабанова, А. В. Сычева // OPUS: Междисциплинарные исследования в археологии : Искусственная деформация головы человека в прошлом Евразии. М. : ИА РАН, 2006. - Вып. 5. - С. 152-163.

4. Балабанова, М. А. Идентификация типов оружия по боевым травмам у сарматов / М. А. Балабанова, Е. В. Перерва // Вооружение сарматов: региональная типология и хронология : докл. к VI Междунар. конф. «Проблемы сарматской археологии и истории» (г. Челябинск, 22-24 мая 2007 г.). Челябинск : Изд. центр ЮУрГУ, 2007. - С. 173-181.

5. Балабанова, М. А. Хозяйственно-культурный уклад и образ жизни сарматских племен по данным античных письменных источников / М. А. Балабанова // Вестник Волгоградского государственного университета. Серия 4, История. Регионоведение. Международные отношения. - 2011. - № 1 (19). - С. 6 12. - DOI: http://doi.org/10.15688/jvolsu4.2011.1.1.

6. Балабанова, М. А. Военное дело сарматоалан и гуннов по данным античных письменных источников / М. А. Балабанова // Вестник Волгоградского государственного университета. Серия 4, История. Регионоведение. Международные отношения. - 2012. - № 1 (21). - C. 13-19. - DOI: http:// doi.org/10.15688/jvolsu4.2012.1.2.

7. Баранова, Г. А. Особенности хронической недостаточности мозгового кровообращения при гиперостозе : автореф. дис. ... канд. мед. наук / Баранова Галина Анатольевна. - Саратов, 2011. $27 \mathrm{c}$.

8. Батиева, Е. Ф. Черепа из курганов междуречья Маныча и Сала (сарматское время) / Е. Ф. Батиева // Сарматы междуречья Сала и Маныча. - Ростов н/Д : Изд-во РГУ, 1992. - Вып. 1. - С. 262-271.

9. Бичурин, Н. Я. Собрание сведений о народах, обитавших в Средней Азии в древние времена. В 3 т. Т. 1 / Н. Я. Бичурин.- М. ; Л. : Изд-во АН CCCP, 1950.-382 c.

10. Бужилова, А. П. Были ли скифы тучными? (Антропологический анализ кремированных останков из скифского погребения) / А. П. Бужилова, М. В. Козловская // Скифы и сарматы в VII-III вв. до н. э.: палеоэкология, антропология и археология. - М. : Изд-во ИА РАН, 2000. -318 с.
11. Бужилова, А. П. Сарматы и боевые столкновения (анализ черепных травм на примере материалов из могильника Сагванский-I) / А. П. Бужилова, И. С. Каменецкий // OPUS: Междисциплинарные исследования в археологии. - М. : Изд-во ИА РАН, 2004. - Вып. 3. - С. 208-213.

12. Бужилова, А. П. Об эндокринных нарушениях у кочевых народов (на примере отдельных представителей сарматской культуры) / А. П. Бужилова, М. А. Соколова, Е. В. Перерва // OPUS: Междисциплинарные исследования в археологии. - М. : Изд-во ИА РАН, 2005. - Вып. 4. - С. 203-216.

13. Воронцов, И. А. Отчет о проведении охранных археологических раскопок ОАН: курганов № 1, 2, 3, 4, 5, 6 курганного могильника «Моисеево» в Жирновском муниципальном районе Волгоградской области и кургана № 1 курганного могильника «Рыбинка-І» в Ольховском муниципальном районе Волгоградской области в 2014 году / И. А. Воронцов. - Волгоград, 2015 // Архив ВОНПЦ.

14. Гайдукова, И. 3. Синдром Морганьи Стюарта - Мореля, кардиомиопатия и повышение уровня аутоантител: сосуществующие или взаимосвязанные состояния? / И. З. Гайдукова, А. П. Ребров // Проблемы женского здоровья. - 2014. - Т. 9, № 3. - С. 64-78.

15. Геродот. История / Геродот. - М. : ОЛМАПРЕСС Инвест, 2004. - 435 с.

16. Гинзбург, В. В. Материалы к антропологии древнего населения Западного Казахстана / В. В. Гинзбург, Б. В. Фирштейн // СМАЭ. - Л. : AH CCCP, 1958. - T. 18. - C. 390-427.

17. Гинзбург, В. В. Этнические связи древнего населения / В. В. Гинзбург // МИА. - 1959. № 60. - С. 563-575.

18. Гиппократ. Избранные книги / Гиппократ. - М. : Гос. изд-во биол. и мед. лит., 1936. - 736 с.

19. Дедов, И. И. Болезни органов эндокринной системы / И. И. Дедов, М. И. Балаболкин, Е. И. Марова. - М. : Медицина, 2000. - 568 с.

20. Демиденко, С. В. Курганный могильник Первомайский I: [Калачев. p-н, Волгогр. обл.] / С. В. Демиденко, Ю. В. Демиденко, В. И. Мамонтов // НАВ. 2006. - Вып. 8. -С. 187-218.

21. Демкин, В. А. Возможности реконструкции погребальной пищи в керамических сосудах из курганов бронзового и раннежелезных веков / В. А. Демкин, Т. С. Демкина // Этнографическое обозрение. 2000. - № 4. - С. 73-81.

22. Докучаева, Н. Ф. К вопросу о лобном гиперостозе / Н. Ф. Докучаева, Н. В. Докучаева, М. К. Андрианова // Атмосфера. Нервные болезни. - 2009. № 2. - С. 21-24.

23. Дробышевский, С. В. Достающее звено. В 2 кн. Кн. 2. Люди / С. В. Дробышевский. - М. : ACT, 2017. -616 c. 
24. Дьяченко, А. Н. Отчет о проведении археологических исследований в Октябрьском районе Волгоградской области у с. Абганерово в 1994 году / А. Н. Дьяченко // Архив археологической лаборатории ВолГУ. -81 л.

25. Дьяченко, А. Н. Отчет о проведении археологических исследований курганных могильников Аксай II и Аксай III в зоне строительства газопровода на территории Октябрьского района Волгоградской области в 2006 г. / А. Н. Дьяченко // Архив археологической лаборатории ВолГУ. - 264 л.

26. Дьяченко, А. Н. Отчет о проведении археологических исследований курганного могильника Ковалевка в Октябрьском районе Волгоградской области в 2016 году / А. Н. Дьяченко // Архив археологической лаборатории ВолГУ.

27. Железчиков, Б. Ф. Раскопки у с. Лятошинка / Б. Ф. Железчиков, А. В. Фалалеев // Археологоэтнографические исследования в Волгоградской области : сб. науч. ст. - Волгоград : Перемена, 1995. C. 23-61.

28. Житецкий, И. А. Астраханские калмыки (наблюдения и заметки) / И. А. Житецкий. - Астрахань : Тип. «Астрах. листка», 1892.-214 с.

29. Жуковская, Н. Л. Пища кочевников Центральной Азии (к вопросу об экологических основах формирования модели питания) / Н. Л. Жуковская // Советская этнография. - 1979. - № 5. - С. 65-75.

30. Ильюков, Л. С. Сарматы междуречья Сала и Маныча / Л. С. Ильюков, М. В. Власкин. - Ростов н/Д : Изд-во Рост. ун-та, 1992. -288 с.

31. Синдром Морганьи - Стюарта - Мореля / М. Ф. Исмагилов [и др.] // Неврологический вестник. - 1994. - Т. 26, вып. 3/4. - С. 72-76.

32. Клавдий Элиан. О животных / Клавдий Элиан // ВДИ. - 1948. - № 2 (24). - С. 223-227.

33. Клепиков, В. М. Отчет о проведении археологических исследований в Октябрьском районе Волгоградской области в 2000 году / В. М. Клепиков // Архив археологической лаборатории ВолГУ. 112 л.

34. Клепиков, В. М. Отчет о проведении археологических исследований в Октябрьском районе Волгоградской области в 2001 г. / В. М. Клепиков // Архив археологической лаборатории ВолГУ.

35. Клепиков, В. М. Отчет о проведении археологических исследований курганных могильников Аксай-IV и Аксай-V в зоне строительства газопровода на территории Октябрьского района Волгоградской области в 2006 г. / В. М. Клепиков. - Волгоград, 2010. - 165 с. // Архив археологической лаборатории ВолГУ.

36. Козак, А. Некоторые результаты антропологического исследования костных останков из раскопок совместной Украинско-Немецкой археологической экспедиции (1998-2000 гг.) / А. Козак. -С. 55-
71. - Электрон. текстовые дан. - Режим доступа: http:/ /ekmair.ukma.edu.ua/bitstream/handle/123456789/7804/ Kozak_Antropolohichni_doslidzhennia.pdf?sequence= 1\&isAllowed=y. - Загл. с экрана.

37. Кондукторова, Т. С. Материалы по палеоантропологии Украины. Палеоантропологический материал сарматского времени / С. Т. Кондукторова // ТИЭ. - 1956. - Т. 33. - С. 166-203.

38. Кривошеев, М. В. Отчет о проведении археологической раскопок к/м Перегрузное-І Октябрьского района, одиночного кургана у пос. Заря Светлоярского района и разведки у с. Костарево в Камышинском районе Волгоградской области в 2007 г. / М. В. Кривошеев // Архив археологической лаборатории ВолГУ.

39. Кригер, В. А. Отчет об археологических исследованиях на территории Волгоградской области в 1982 г. / В. А. Кригер // Архив археологической лаборатории ВолГУ.

40. Круц, С. И. Антропологические материалы из сарматских погребений у с. Пороги // Симоненко, А. В. Сарматы северо-западного Причерноморья в І в. н. э. / А. В. Симоненко, Б. И. Лобай. Киев : Наукова думка, 1991. - С. 131-135.

41. Латышев, В. В. Известия древних писателей о Скифии и Кавказе / В. В. Латышев // ВДИ. 1948. - № 2 (24). - С. 215-314; № 3 (25). - С. 217-330.

42. Латышев, В. В. Известия древних писателей о Скифии и Кавказе / В. В. Латышев // ВДИ. 1949. - № 4 (30). - С. 227-304.

43. Лутс, Л. Л. Проблемы васкулярной патологии мозга и психофармакологии / Л. Л. Лутс, А. В. Пашков // Материалы І съезда невропатологов, нейрохирургов и психиаторов ЭССР, 31 марта - 1 апр. 1977 г. - Таллин : [б. и.], 1977. - С. 27.

44. Максименко, В. Е. Отчет о раскопках курганов Тацинском районе ростовской области 1978 г. / В. Е. Максименко // Архив ИА РАН. - Р-1. - № 7094.

45. Максименко, В. Е. Раскопки курганных могильников на р. Быстрая / В. Е. Максименко, С. И. Безуглов, А. В. Захаров // Археологические открытия 1983 года. - М. : Наука, 1985. - С. 123.

46. Мамонтов, В. И. Материалы курганного могильника «Новый Рогачик» / В. И. Мамонтов // Нижневолжский археологический вестник. 1998. - Вып. 1. - С. 87-103.

47. Мамонтов, В. И. Древнее население левобережья Дона (по материалам курганного могильника Первомайский VII) / В. И. Мамонтов. - Волгоград : Изд-во ВолГУ, 2000. - 145 с.

48. Мамонтов, В. И. Отчет о работе Донской экспедиции археологической лаборатории НИС ВГПУ в Волгоградской области в 2002 г. / В. И. Мамонтов // Архив ВОКМ. - № 177. - 52 л.

49. Марцеллин Аммиан. Римская история / Аммиан Марцеллин. - СПб. : Алетейя, 1994. -559 с. 
50. Медведев, А. П. Очерк этнографии сарматов / А. П. Медведев // Вестник Воронежского государственного университета. Серия: История, Политология. Социология. - 2009. - № 2. - С. 3-14.

51. Мыськов, Е. П. Отчет о раскопках могильника Царев, проведенных Волго-Ахтубинским отрядом археологической экспедиции Волгоградского пединститута в 1990 г. / Е. П. Мыськов // Архив ВОКМ. - № 68. -20 л.

52. Мыськов, Е. П. Отчет об археологических исследованиях, проведенных Волго-Ахтубинской археологической экспедицией Волгоградского государственного педагогического университета в Городищенском, Дубовском, Октябрьском и Клетском районах Волгоградской области в 2006 году / Е. П. Мыськов // Архив ВОКМ.

53. Небольсин, П. Очерки быта калмыков Хошоутовского улуса / П. Небольсин. - СПб. : Тип. К. Крайя, 1852. - 192 с.

54. Некачалов, В. В. Патология костей и суставов. Руководство / В. В. Некачалов. - СПб. : Сотис, 2000. $-288 \mathrm{c}$.

55. Перерва, Е. В. Палеопатология поздних сарматов из могильников Есауловского Аксая / Е. В. Перерва // OPUS: Междисциплинарные исследования в археологии. - М. : Изд-во ИА РАН, 2002. - Вып. 1/2. - С. 141-152.

56. Перерва, Е. В. Население сарматской эпохи по антропологическим материалам из могильников Нижнего Поволжья и Нижнего Дона : дис. ... канд. ист. наук / Перерва Евгений Владимирович. M., 2005. $-603 \mathrm{c}$.

57. Перерва, Е. В. Рентгенологическое исследование деформированных черепов эпохи средней бронзы с территории Нижнего Поволжья (палеопатологический аспект) / Е. В. Перерва // Вестник Волгоградского государственного университета. Серия 4, История. Регионоведение. Международные отношения. - 2013. - № 2 (24). - C. 7-19. - DOI: http://doi.org/10.15688/jvolsu4.2013.2.1.

58. Перерва, Е. В. Рентгенологическое исследование деформированных черепов золотоордынского времени с территории Нижнего Поволжья (палеопатологический аспект) / Е. В. Перерва // Beстник археологии, антропологии и этнографии. 2015. - № 2 (29). - C. 98-114.

59. Плиний Старший. Естественная история / Плиний Старший ; пер. Н. М. Подземской // Античная география. - М. : Географгиз, 1953. C. 238-262.

60. Полиэн. Стратегемы : пер. с греч. / Полиен ; под общ. ред. А. К. Нефедкина. - СПб. : Евразия, 2002. $-608 \mathrm{c}$.

61. Помпоний Мела. Местоположение земли / Помпоний Мела ; пер. С. К. Апта // Античная география. -М. : Географгиз, 1953. - С. 176-238.
62. Прямухин, А. Н. Отчет об археологических исследованиях могильника Сохранный в Нехаевском районе Волгоградской области в 2015 году / А. Н. Прямухин. - Волгоград, 2017. - 122 с. // Архив ВОНПЦ.

63. Пустынников, В. М. Лобный гиперостоз как проявление возрастных изменений в костях черепа / В. М. Пустынников // Тюменский медицинский журнал. - 2014. - Т. 16, № 2. - С. 30.

64. Путешествие в восточные страны Плано Карпини и Рубрука. - М. : Гос. изд-во геогр. лит., 1957. $-272 \mathrm{c}$.

65. Сергацков, И. В. Отчет о раскопках курганов близ с. Царев в 1998 г. / И. В. Сергацков // Архив археологической лаборатории ВолГУ.

66. Сергацков, И. В. Сарматские курганы на Иловле / И. В. Сергацков. - Волгоград : Изд-во ВолГУ, 2000. -396 с.

67. Сергацков, И. В. Отчет о раскопках курганного могильника Ольховка I на трассе строительства магистрального газопровода «Починки - Изобильное». Волгоград, 2003 г. / И. В. Сергацков // Архив археологической лаборатории ВолГУ. - 193 л.

68. Соколова, М. А. Образ жизни и гормональные нарушения на примере сарматских племен / М. А. Соколова // Экология и демография человека в прошлом и настоящем : материалы Третьих антропол. чтений к 75-летию со дня рождения акад. В.П. Алексеева. - М. : Энцикл. рос. деревень, 2004. - C. $188-190$.

69. Соллий Апполинарий Сидоний. Стихотворения / Соллий Апполинарий Сидоний // ВДИ. 1949. - № 4 (30). - С. 288-289.

70. Страбон. География в 17 книгах / Страбон ; пер., вступ. ст. и коммент. Г. А. Стратановского. - М. : Ладомир, 1994. - 944 с.

71. Тацит Публий Корнелий. Анналы. Малые произведения. История / Тацит Публий Корнелий. М. : АСТ : Ладомир, 2002. -811 c.

72. Фирштейн, Б. В. Антропологические данные к вопросу о великом переселении народов : Авары и сарматы / Б. В. Фирштейн, Т. А. Тот. - Л. : Наука, 1970. - $201 \mathrm{c}$.

73. Флавий Вописк Сиракузянин. Проб / Флавий Вописк Сиракузянин // Властелины Рима : Биографии римских императоров от Адриана до Диоклетиана / пер. С. Н. Кондратьева. - М. : Наука, 1992. - C. 298-310.

74. Хазанов, А. М. Социальная история скифов / А. М. Хазанов. - М. : Наука, 1975. - 336 с.

75. Юлес, М. Диагностика и патофизиологические основы нейроэндокринных заболеваний / М. Юлес, И. Холло. - Будапешт : Изд-во Акад. наук Венгрии, 1976. -882 с.

76. Яблонский, Л. Т. Антропологические данные к этногенезу народов Поволжья (по материа- 
лам Поволжской экспедиции) / Л. Т. Яблонский // НАВ. - Волгоград : Изд-во ВолГУ, 2002. - Вып. 5. C. $24-46$.

77. Anderson, T. An Anglo-Saxon case of hyperostosis frontalis interna from Sarre / T. Anderson // Kent. Journal of Paleopathology. - 1994. - № 6 (1). P. 29-34.

78. Anton, S. C. Endocranial Hyperostosis in Sangiran 2, Gibraltar 1, and Shanidar 5 / S. C. Anton // American journal of physical anthropology. - 1997. № 102. - P. 111-122.

79. Armelagos, G. J. Hyperostosis frontalis interna: ANubian case/G. J. Armelagos, O. D. Chrisman // American Journal of Physical Anthropology. - 1988. № 76. - P. 25-28.

80. Full Penetrance of Morgagni-Stewart-Morel Syndrome in a 75-Year-Old Woman: Case Report and Review of the Literature / F. Attanasio [et al.] // J. Clin. Endocrinol. Metab. - 2013. - Febr., № 98(2). - P. 453-457.

81. Bebel, A. A case of hyperostosis frontalis interna from Deir el-Bahari, Egypt / A. Bebel, A. Golijewskaja // Bioarchaeology of the Near East. 2015. - № 9. - P. 45-54.

82. Caughey, J. E. The etiology of hyperostosis cram! (Metabolic craniopathy) / J. E. Caughey // The Journal of Bone and Joint Surgery. - 1958. - Nov., vol. 40 B, № 4. - P. 701-721.

83. Chudá, E. P. Hyperostosis frontalis interna $-\mathrm{a}$ find in women individual from Modern Times (St. Martin Cathedral, Spisska Kapitula, Slovakia) / E. P. Chudá, M. Dornhoferova // Antropowebzin. - 2011. - № 2. P. 97-101.

84. Two Neolithic Cases of Hyperostosis Frontalis Interna / W. Devriendt [et al.] // International Journal of Osteoarchaeology International Journal of Osteoarchaeology. - 2004. - № 14. - P. 414-418.

85. Hyperostosis Frontalis Interna in Postmenopausal Women-Possible Relation to Osteoporosis / D. Djonic [et al.] // Women \& Health. 2016. - P. 1-23.

86. Flohr, S. Hyperostosis frontalis interna A marker of social status? Evidence from the BronzeAge "high society" of Qatna, Syria / S. Flohr, C. Witzel // HOMO - Journal of Comparative Human Biology. 2011. - № 62. - P. 30-43.

87. Garralda, M. D. Hyperostosis frontalis interna in a Neandertal from Marillac (Charente, France) / M. D. Garralda, B. Maureille, B. Vandermeersch // Journal of Human Evolution. - 2014. - P. 1-9.

88. Ginsburg, V. V. An Anthropological Characterization of the Sarmatians in the Volga Area / V. V. Ginsburg // Annales historico-naturales Musei Nationalis Hungarici (Pars Anthropologica). Hungury: Tomus 60, 1968. - P. 307-311.

89. Glab, H. Hyperostosis frontalis interna, a genetic disease? Two medieval cases from Southern
Poland/ H. Glab, K. Szostek, K. Kaczanowski // HOMO Journal of Comparative Human Biology. - 2006. № 57. - P. 19-27.

90. Appearance of hyperostosis frontalis interna in some osteoarcheological series from Hungary / T. Hajdu [et al.] // HOMO - J. Comp. Hum. Biol. - № 60 (3). - P. 185-205. - DOI: https://doi.org/ 10.1016/j.jchb.2008.07.004.

91. Hawkins, T. D. Incidence of hyperostosis frontalis interna in patients at a general hospital and at a mental hospital / T. D. Hawkins, L. Martin // Journal of Neurol. Neurosurg. Psychiat. - 1965. - № 28. P. 171-174.

92. Hyperostosis Frontalis Interna: An Anthropological Perspective / I. Hershkovitz [et al.] // American journal of physical anthropology. - 1999. № 109. - P. 303-325.

93. Evidence of a Genetic Basis of MorgagniStewart-Morel Syndrome. A Case Report of Identical Twins / M. F. Koller [et al.] // Neurodegenerative Disease. -2005 . - № 2. - P. 56-60.

94. Hyperostosis frontalis interna as a novel finding in Unverricht - Lundborg disease / M. Korja [et al.] // Neurology. - 2007. - Mar. 27. - P. 1077-1078.

95. Mant, M. Paleopathology of human remains at ancient Mendes (Tell er-Rub'a), Egypt / M. Mant // Bioarcheology of the Near East. - 2014. - № 8. P. 1-27.

96. Hyperostosis frontalis interna: criteria for sexing and aging a skeleton / H. May [et al.] // Int. J. Legal Med. - 2011. - № 125. - P. 669-673.

97. Intracranial Volume, Cranial Thickness, and Hyperostosis Frontalis Interna in the Elderly/ H. May [et al.] // American journal of human biology. - 2012. № 24. - P. 812-819.

98. Molnár, E. Paleopathological evaluation of Hungarian skeletal remains from the $7^{\text {th }}-9^{\text {th }}$ centuries AD / E. Molnár, A. Marcsik // Antropofagia Portuguesa. - 2002. - № 19. - P. 85-99.

99. Moore, S. Hyperostosis Cranii (Cranial Hyperostosis) / S. Moore. - Springfield, IL: C.C. Thomas, 1955. $-226 \mathrm{p}$.

100. Mulher, D. M. BriefCommunication: Unusual Finding at Pueblo Bonito: Multiple Cases of Hyperostosis Frontalis Interna / D. M. Mulher, C. A. Wilczak, J. Ch. Dudar // American Journal of Physical Anthropology. - 2006. - № 130. - P. 480-484.

101. Nowakowski, D. A case of Hyperostosis frontalis interna (HFI) in a medieval skeleton from Lower Silesia (Poland) / D. Nowakowski, B. Kwiatkowska // Journal of Paleopathology. - 2005. - № 17 (1). - P. 5-9.

102. Ortner, D. J. Identification of pathological conditions in human skeletal remains / D. J. Ortner, W. G. Putschar. - Washington, DC : Smithonian Institution Press, 1981. - 479 p. - (Smithonian contributions anthropological ; № 28). 
103. Powers, N. Human osteology method statement / N. Powers. -64 p. - Publ. online Mar. 2008 // Museum of London. - Electronic text data. - Mode of access: https://www.museumoflondon. org.uk/application/files/5014/7308/7418/Osteology MethodStatementrevised2012.pdf. - Title from screen.

104. Raikos, A. Etiopathogenesis of hyperostosis frontalis interna: A mystery still / A. Raikos [et al.] // Annals of Anatomy. - 2011. - № 193. - P. 453-458.

105. Roberts, Ch. The Archaeology of Disease / Ch. Roberts, K. Manchester. $-3^{\text {rd }}$ ed. - Manchester : The History Press, 2010. - 338 p.

106. Ruhli, F. J. Hyperostosis frontalis interna : archaeological evidence of possible microevolution of human sex steroids? / F. J. Ruhli, T. Boni, M. Henneberg // HOMO - Journal of Comparative Human Biology. - 2004. - № 55. - P. 91-99.

107. Shahin, A. A. Hyperostosis frontalis interna: An Egyptian case referred to thesecond dynas ty $(2890-2650$ BC) from Tarkhan - Egypt / A. A. Shahin, S. Alhoseiny, M. Aldali // The Egyptian Rheumatologist. 2014. - № 36. - P. 41-45.

108. She, R. Hyperostosis Frontalis Interna: Case Report and Review of Literature / R. She, J. Szakacs // Annals of Clinical \& Laboratory Science. - 2004. Vol. 34, № 2. - P. 206-208.

109. Singh, K. Hyperostosis frontalis interna $-\mathrm{a}$ rare Benign incidental finding / K. Singh, S. Shrinuvasan, R. Chidambaram // Indian Journal of Medical Case Reports. - 2017. - Apr.-June, vol. 6 (2). P. 15-17.

110. Smith, S. Hyperostosis frontalis interna / S. Smith, R. E. Hemphill // J. Neurol. Neurosurg. Psychiat. - 1956. - № 19. - P. 42-45.

111. Aufderheide, C. The Cambridge Encyclopedia of Human Paleopathology / A. C. Aufderheide, C. Rodriguez-Martin.-Cambridge : Cambridge University Press, 1998. $-478 \mathrm{p}$.

112. Toase, L. An osteological analysis of skeletons from the Roman necropolis of Apulum, Alba Iulia, Romania / L. Toase // Buletinul Cercurilor Ştiințifice Studențteşti. - 2014. - № 20. - P. 83-96.

113. Trelles, O. J. Mario Mendes Síndrome de Stewart - Morel (Hiperostosis Frontal interna) / O. J. Trelles. - Santiago : Prensas de la universidad de chile, 1936. - P. 53-64.

114. Waldron, T. Paleopathology/ T. Waldron.Cambridge : Cambridge University Press The Edinburgh Building, 2009.-279 p.

115. Watrous, A. C. Hyperostosis frontalis interna in ancient Egyptians / A. C. Watrous, S. C. Anton, A. M. Plourde // American Journal of Physical Anthropology. - 1993. - P. 205.

116. Weiss, E. Paleopathology in Perspective. Bone health and disease through time / E. Weiss. N. Y. ; L. : [s. n.], 2015. - 251 p.
117. Yaxiong Li. Hyperostosis Frontalis Interna in a Child With Severe Traumatic Brain Injury/Yaxiong Li, Xin Wang, Yan Li // Child Neurology Open. 2017. - Vol. 4. - P. 1-4.

\section{REFERENCES}

1. Balabanova M.A. Antropologiya drevnego naseleniya Yuzhnogo Priuralya $i$ Nizhnego Povolzhya. Ranniy zheleznyy vek [Anthropology of the Ancient Population of the Southern Urals and the Lower Volga Region. The Early Iron Age]. Moscow, Nauka Publ., 2000. 133 p.

2. Balabanova M.A. O drevnikh makrokefalakh Vostochnoy Evropy [About the Ancient Macroecaphiles of Eastern Europe]. OPUS: Mezhdistsiplinarnye issledovaniya $v$ arkheologii [OPUS: Interdisciplinary Research in Archaeology]. Moscow, Izd-vo IA RAN, 2004, iss. 3, pp. 171-187.

3. Balabanova M.A. Rentgenologicheskoe issledovanie pozdnesarmatskikh cherepov [X-ray Examination of Late Sarmatian Skulls]. OPUS: Mezhdistsiplinarnye issledovaniya $v$ arkheologii: Iskusstvennaya deformatsiya golovy cheloveka $v$ proshlom Evrazii [OPUS: Interdisciplinary Research in Archaeology: Artificial Deformation of the Human Head in the Past of Eurasia]. Moscow, Izd-vo IA RAN, 2006, iss. 5, pp. 152-163.

4. Balabanova M.A., Pererva E.V. Identifikatsiya tipov oruzhiya po boevym travmam $u$ sarmatov [Identification of Weapons Types by Combat Injuries in Sarmatians]. Vooruzhenie sarmatov: regionalnaya tipologiya $i$ khronologiya: doklady $k$ VI mezhdunarodnoy konferentsii "Problemy sarmatskoy arkheologii $i$ istorii" ( $g$. Chelyabinsk, 22-24 maya 2007 g.) [Arms of the Sarmatians: Regional Typology and Chronology: Reports to the $6^{\text {th }}$ International Conference "Problems of Sarmatian Archaeology and History" (Chelyabinsk, 22-24 May 2007)]. Chelyabinsk, YuUrGU Publ., 2007, pp. 173-181.

5. Balabanova M.A. Khozyaystvennokulturnyy uklad i obraz zhizni sarmatskikh plemen po dannym antichnykh pismennykh istochnikov [The Economic and Cultural Way of Life and Lifestyle of the Sarmatian Tribes according to Ancient Written Sources]. Vestnik Volgogradskogo gosudarstvennogo universiteta. Seriya 4, Istoriya. Regionovedenie. Mezhdunarodnye otnosheniya [Science Journal of Volgograd State University. History. Area Studies. International Relations], 2011, no. 1 (19), pp. 6-12. DOI: http://dx.doi.org/10.15688/jvolsu4.2011.1.1.

6. Balabanova M.A. Voennoe delo u sarmatoalan i gunnov po dannym antichnykh pismennykh istochnikov [The Military Affairs of the Sarmato-Alans and the Huns according to Ancient Written Sources]. 
Vestnik Volgogradskogo gosudarstvennogo universiteta. Seriya 4. Istoriya. Regionovedenie. Mezhdunarodnye otnosheniya [Science Journal of Volgograd State University. History. Area Studies. International Relations], 2011, no. 1 (21), pp. 13-19. DOI: http://dx.doi.org/10.15688/jvolsu4.2012.1.2.

7. Baranova G.A. Osobennosti khronicheskoy nedostatochnosti mozgovogo krovoobrashcheniya pri giperostoze: avtoref. dis. ... kand. med. nauk [Features of Chronic Cerebral Circulatory Insufficiency at Hyperostosis. Cand. med. sci. abs. diss.]. Saratov, $2011.27 \mathrm{p}$.

8. Batieva E.F. Cherepa iz kurganov mezhdurechya Manycha i Sala (sarmatskoe vremya) [Skulls from the Mounds of the Manych-Sala Interfluve (the Sarmatian Time)]. Sarmaty mezhdurechya Sala i Manycha [Sarmatians of the Manych and Sala Interfluve]. Rostov-on-Don, Izd-vo RGU, 1992, iss. 1, pp. 262-271.

9. Bichurin Kh.Ya. Sobranie svedeniy o narodakh, obitavshikh $v$ Sredney Azii $v$ drevnie vremena. V 3 t. T. 1 [Collected Data about the Peoples Inhabiting Central Asia in Ancient Times. In 3 vols. Vol. 1]. Moscow; Leningrad, Izd-vo AN SSSR, 1950. $382 \mathrm{p}$.

10. Buzhilova A.P., Kozlovskaya M.V. Byli li skify tuchnymi? (Antropologicheskiy analiz kremirovannykh ostankov iz skifskogo pogrebeniya) [Were the Scythians Fat? (Anthropological Analysis of Cremated Remains from the Scythian Burial)]. Skify $i$ sarmaty $v$ VII-III $v v$. do n.e.: paleoekologiya, antropologiya $i$ arkheologiya [Scythians and Sarmatians in the $7^{\text {th }}-3^{\text {rd }}$ Centuries BC: Paleoecology, Anthropology and Archaeology]. Moscow, Izd-vo IA RAN, 2000.318p.

11. Buzhilova A.P., Kamenetskiy I.S. Sarmaty i boevye stolknoveniya (analiz cherepnykh travm na primere materialov iz mogilnika Sagvanskiy-I) [Sarmatians and Fighting Collisions (Analysis of Cranial Injuries on the Example of Materials from the Burial Ground Sagvansky-I)]. OPUS: Mezhdistsiplinarnye issledovaniya $v$ arkheologii [OPUS: Interdisciplinary Research in Archaeology]. Moscow, Izd-vo IA RAN, 2004, iss. 3, pp. 208-213.

12. Buzhilova A.P., Sokolova M.A., Pererva E.V. Ob endokrinnykh narusheniyakh u kochevykh narodov (na primere otdelnykh predstaviteley sarmatskoy kultury) [About Endocrine Disorders in Nomadic Peoples (on the Example of Sarmatian Culture's Representatives)]. OPUS: Mezhdistsiplinarnye issledovaniya $v$ arkheologii [OPUS: Interdisciplinary Research in Archaeology]. Moscow, Izd-vo IA RAN, 2005, iss. 4, pp. 203-216.

13. Vorontsov I.A. Otchet o provedenii okhrannykh arkheologicheskikh raskopok OAN: kurganov № 1, 2, 3, 4, 5, 6 kurgannogo mogilnika
«Moiseevo» v Zhirnovskom munitsipalnom rayone Volgogradskoy oblasti i kurgana №1 kurgannogo mogilnika «Rybinka-I» v Olkhovskom munitsipalnom rayone Volgogradskoy oblasti v 2014 godu [Report on the Conduct of Archaeological Excavations OAS of Barrows 1, 2, 3, 4, 5, 6 of the Burial Mound Moiseevo in the Zhirnovsky Municipal District of the Volgograd Region and Barrow 1 of the Burial Mound Rybinka-I in the Olkhovsky Municipal District of the Volgograd Region in 2014]. Volgograd, 2015. Arkhiv VONPTs.

14. Gaydukova I.Z., Rebrov A.P. Sindrom Morganyi-Styuarta-Morelya, kardiomiopatiya i povyshenie urovnya autoantitel: sosushchestvuyushchie ili vzaimosvyazannye sostoyaniya? [The MorgagniStewart-Morel Syndrome, Cardiomyopathy and Increased Levels of Autoantibodies: Coexisting or Interrelated States?]. Problemy zhenskogo zdorovya [Problems of Women's Health], 2014, vol. 9, no. 3, pp. 64-78.

15. Stratanovskiy G.A., ed. Gerodot. Istoriya [Herodotus. History]. Moscow, AST Moskva Publ., $2007.700 \mathrm{p}$.

16. Ginzburg V.V., Firshtein B.V. Materialy k antropologii drevnego naseleniya Zapadnogo Kazakhstana [Materials to the Anthropology of Ancient Population of Western Kazakhstan]. Sbornik muzeya etnologii $i$ etnografii [Collection of the Museum of Ethnology and Ethnography]. Leningrad, Izd-vo AN SSSR, 1958, vol. 18, pp. 390-427.

17. Ginzburg V.V. Etnicheskie svyazi drevnego naseleniya [Ethnic Ties of the Ancient Population]. Materialy $i$ issledovaniya po arkheologii SSSR [Materials and Research on Archaeology of the USSR], 1959 , no. 60 , pp. 563-575.

18. Hippocrates. Izbrannye knigi [Selected Books]. Moscow, Gos. izd-vo boil. i med. lit., 1936. $736 \mathrm{p}$.

19. Dedov I.I., Balabolkin M.I., Marova E.I. Bolezni organov endokrinnoy sistemy [Diseases of the Endocrine System]. Moscow, Meditsina Publ., 2000.568 p.

20. Demidenko S.V., Demidenko Yu.V., Mamontov V.I. Kurgannyy mogilnik Pervomayskiy I: (Kalachev. r-n, Volgogr. obl.) [The Burial Mound Pervomaisky I: (Kalachev District of the Volgograd Region)]. Nizhnevolzhskiy arkheologicheskiy vestnik [The Lower Volga Archaeological Bulletin], 2006, iss. 8, pp. 187-218.

21. Demkin V.A., Demkina T.S. Vozmozhnosti rekonstruktsii pogrebalnoy pishchi $v$ keramicheskikh sosudakh iz kurganov bronzovogo i rannezheleznykh vekov [Possibilities of Funeral Food Reconstruction in Ceramic Vessels from Barrows of the Bronze and Early Iron Ages]. Etnograficheskoe obozrenie [Ethnographic Review], 2000, no. 4, pp. 73-81.

22. Dokuchaeva N.F., Dokuchaeva N.V., Andrianova M.K. K voprosu o lobnom giperostoze 
[On the Frontal Hyperostosis]. Atmosfera. Nervnye bolezni [Atmosphere. Nervous Diseases], 2009, no. 2, pp. 21-24.

23. Drobyshevskiy S.V. Dostayushchee zveno. $V 2$ kn. Kn. 2. Lyudi [Remaining Link. In 2 Books. Book 2. People]. Moscow, AST Publ., 2017.616 p.

24. Dyachenko A.N. Otchet o provedenii arkheologicheskikh issledovaniy v Oktyabrskom rayone Volgogradskoy oblasti u s. Abganerovo v 1994 godu [Report on Archaeological Research in the Oktyabrsky District of the Volgograd Region near the Abganerovo Village in 1994]. Arkhiv arkheologicheskoy laboratorii VolGU [Archive of the Archaeological Laboratory of VolSU]. $81 \mathrm{~L}$.

25. Dyachenko A.N. Otchet o provedenii arkheologicheskikh issledovaniy kurgannykh mogilnikov Aksai II i Aksai III v zone stroitelstva gazoprovoda na territorii Oktyabrskogo rayona Volgogradskoy oblasti v 2006 g. [Report on the Archaeological Research of the Aksai II and Aksai III Burial Mounds in the Zone of Gas Pipeline Construction in the Oktyabrsky District of the Volgograd Region in 2006]. Arkhiv arkheologicheskoy laboratorii VolGU [Archive of the Archaeological Laboratory of VolSU]. 264 L.

26. Dyachenko A.N. Otchet o provedenii arkheologicheskikh issledovaniy kurgannogo mogilnika Kovalevka v Oktyabrskom rayone Volgogradskoy oblasti v 2016 godu [Report on the Archaeological Research of the Kovalevka Burial Mound in the Oktyabrsky District of the Volgograd Region in 2016]. Arkhiv arkheologicheskoy laboratorii VolGU [Archive of the Archaeological Laboratory of VolSU].

27. Zhelezchikov B.F., Falaleev A.V. Raskopki u s. Lyatoshinka [Excavations near the Lyatoshinka Village]. Arkheologo-etnograficheskie issledovaniya $v$ Volgogradskoy oblasti: sb. nauch. st. [Archaeological and Ethnographic Research in the Volgograd Region. Collected Papers]. Volgograd, Peremena Publ., 1995, pp. 23-61.

28. Zhitetskiy I.A. Astrakhanskie kalmyki (nablyudeniya $i$ zametki) [Astrakhan Kalmyks (Observations and Notes)]. Astrakhan, Astrakh. Listka Publ., 1892.214 p.

29. Zhukovskaya N.L. Pishcha kochevnikov Tsentralnoy Azii (K voprosu ob ekologicheskikh osnovakh formirovaniya modeli pitaniya) [Nutrition of Central Asia Nomads (on the Ecological Principles of Nutrition Model Formation)]. Sovetskaya etnografiya [Soviet Ethnography], 1979, no. 5, pp. 65-75.

30. Ilyukov L.S., Vlaskin M.V. Sarmaty mezhdurechya Sala i Manycha [Sarmatians in the SalaManych Interfluve]. Rostov-on-Don, Izd-vo Rostovskogo un-ta, 1992. 288 p.

31. Ismagilov M. F., Khasanova D. R., Galimullina Z. A., Sharashenidze D. M. Sindrom
Morgani - Styuarta - Morelya [The Morgagni-StewartMorel Syndrome]. Nevrologicheskiy vestnik [Neurological Messenger], 1994, vol. 26, iss. 3-4, pp. 72-76.

32. Claudius Aelianus. O zhivotnykh [About Animals]. VDI [Journal of Ancient History], 1948, no. 2 (24), pp. 223-227.

33. Klepikov V.M. Otchet o provedenii arkheologicheskikh issledovaniy v Oktyabrskom rayone Volgogradskoy oblasti v 2000 godu [Report on the Archaeological Research in the Oktyabrsky District of the Volgograd Region in 2000]. Arkhiv arkheologicheskoy laboratorii VolGU [Archive of the Archaeological Laboratory of VolSU].

34. Klepikov V.M. Otchet o provedenii arkheologicheskikh issledovaniy v Oktyabrskom rayone Volgogradskoy oblasti v $2001 \mathrm{~g}$. [Report on the Archaeological Research in the Oktyabrsky District of the Volgograd Region in 2001]. Arkhiv arkheologicheskoy laboratorii VolGU [Archive of the Archaeological Laboratory of VolSU].

35. Klepikov V.M. Otchet o provedenii arkheologicheskikh issledovaniy kurgannykh mogilnikov Aksai-IV i Aksai-V v zone stroitelstva gazoprovoda na territorii Oktyabrskogo rayona Volgogradskoy oblasti v 2006 g. [Report on the Archaeological Research of the Aksai-IV and Aksai-V Burial Mounds in the Zone of Gas Pipeline Construction in the Oktyabrsky District of the Volgograd Region in 2006]. Arkhiv arkheologicheskoy laboratorii VolGU [Archive of the Archaeological Laboratory of VolSU].

36. Kozak A. Nekotorye rezultaty antropologicheskoego issledovaniya kostnykh ostankov iz raskopok sovmestnoy UkrainskoNemetskoy arkheologicheskoy ekspeditsii (19982000 gg.) [Some Results of Anthropological Research of Bone Remains from Excavations of the Joint Ukrainian-German Archaeological Expedition (19982000)]. Belsk, 2000, pp. 55-71. URL: http://ekmair. ukma.edu.ua/bitstream/handle/123456789/7804/ Kozak_Antropolohichni_doslidzhennia.pdf?sequence= 1\&isAllowed=y.

37. Konduktorova T.S. Materialy po paleoantropologii Ukrainy. Paleoantropologicheskiy material sarmatskogo vremeni [Materials on the Paleoanthropology of Ukraine. Paleoanthropological Material of the Sarmatian time]. Trudy Instituta etnografii [Proceedings of the Institute of Ethnography], 1956, vol. 33, pp. 166-203.

38. Krivosheev M.V. Otchet o provedenii arkheologicheskoy raskopok k/m Peregruznoe-I Oktyabrskogo rayona, odinochnogo kurgana u pos. Zarya Svetloyarskogo rayona i razvedki u s. Kostarevo v Kamyshinskom rayone Volgogradskoy oblasti v 2007 g. [Report on the Archaeological Excavations in the Peregruznoe-I Burial Mound of the Oktyabrsky 
District, a Solitary Mound near the Village Zarya of the Svetloyarsky District and the Village Kostarevo in the Kamyshinsky District of the Volgograd Region in 2007]. Arkhiv arkheologicheskoy laboratorii VolGU [Archive of the Archaeological Laboratory of VolSU].

39. Kriger V.A. Otchet ob arkheologicheskikh issledovaniyakh na territorii Volgogradskoy oblasti v 1982 g. [Report on Archaeological Research in the Volgograd Region in 1982]. Arkhiv arkheologicheskoy laboratorii VolGU [Archive of the Archaeological Laboratory of VolSU].

40. Kruts S.I., Simonenko A.V., Lobay B.I. Antropologicheskie materialy iz sarmatskikh pogrebeniy u s. Porogi [Anthropological Materials from the Sarmatian Burials near the Village Porogi]. Sarmaty severo-zapadnogo Prichernomorya vI v. n.e. [Sarmatians of the North-Western Black Sea Coast in the $1^{\text {st }}$ Century AD]. Kiev, Naukova dumka Publ., 1991, pp. 131-135.

41. Latyshev V.V. Izvestiya drevnikh pisateley o Skifii i Kavkaze [News of Ancient Writers about Scythia and the Caucasus]. VDI [Journal of Ancient History], 1948, no. 2 (24), pp. 215-314; no 3 (25), pp. 217-330.

42. Latyshev V.V. Izvestiya drevnikh pisateley o Skifii i Kavkaze [News of Ancient Writers about Scythia and the Caucasus]. VDI [Journal of Ancient History], 1949, no. 2 (28), pp. 271-356; no. 3 (29), pp. 227-305.

43. Luts L.L., Pashkov A.V. Problemy vaskulyarnoy patologii mozga i psikhofarmakologii [Problems of Vascular Pathology of the Brain and Psychopharmacology]. Materialy I syezda nevropatologov, neyrokhirurgov i psikhiatorov ESSR, 31 marta - 1 apr. $1977 \mathrm{~g}$. [Proceedings of the $1^{\text {st }}$ Congress of Neurologists, Neurosurgeons and Psychiatrists of the Estonian SSR, March 31-April 1, 1977]. Tallin, 1977, p. 27.

44. Maksimenko V.E. Otchet o raskopkakh kurganov Tatsinskom rayone rostovskoy oblasti 1978 g. [Report on the Excavation of Mounds in the Tatsin District of the Rostov Region in 1978.]. Arkhiv IA RAN, R-1, no. 7094.

45. Maksimenko V.E., Bezuglov S.I., Zakharov A.V. Raskopki kurgannykh mogilnikov na r. Bystraya [Excavations of Burial Mounds on the River Bystraya]. Arkheologicheskie otkrytiya 1983 goda [Archaeological Discoveries of 1983]. Moscow, Nauka Publ., 1985, p. 123.

46. Mamontov V.I. Materialy kurgannogo mogilnika «Novyy Rogachik» [Materials of the Burial Mound Novyy Rogachik]. Nizhnevolzhskiy arkheologicheskiy vestnik [The Lower Volga Archaeological Bulletin], 1998, iss. 1, pp. 87-103.

47. Mamontov V.I. Drevnee naselenie levoberezhya Dona (po materialam kurgannogo mogilnika Pervomayskiy VII) [The Ancient Population of the Left Bank of the Don (Based on the Materials of the Burial Mound Pervomayskiy VII]. Volgograd, Izd-vo VolGU, 2000. 145 p.

48. Mamontov V.I. Otchet o rabote Donskoy ekspeditsii arkheologicheskoy laboratorii NIS VGPU v Volgogradskoy oblasti v 2002 g. [Report on the Work of the Don Expedition of the Archaeological Laboratory of the Volgograd Pedagogical Institute in the Volgograd Region in 2002.]. Arkhiv VOKM, no. $177,52 \mathrm{~L}$.

49. Martsellin Ammian. Rimskaya istoriya [Roman History]. Saint Petersburg, Aleteya Publ., $1994.559 \mathrm{p}$.

50. Medvedev A.P. Ocherk etnografii sarmatov [Essay on the Ethnography of the Sarmatians]. Vestnik $V G U$. Seriya: Istoriya, Politologiya. Sotsiologiya [Bulletin of the VSU. Series: History, Political Science. Sociology], 2009, no. 2, pp. 3-14.

51. Myskov E.P. Otchet o raskopkakh mogilnika Tsarev, provedennykh Volgo-Akhtubinskim otryadom arkheologicheskoy ekspeditsii Volgogradskogo pedinstituta v $1990 \mathrm{~g}$. [Report on the Excavations of the Tsarev Burial Ground, Conducted by the VolgoAkhtuba Group of the Archaeological Expedition of the Volgograd Pedagogical Institute in 1990]. Arkhiv VOKM, no. 68, $20 \mathrm{~L}$.

52. Myskov E.P. Otchet ob arkheologicheskikh issledovaniyakh, provedennykh Volgo-Akhtubinskoy arkheologicheskoy ekspeditsiey Volgogradskogo gosudarstvennogo pedagogicheskogo universiteta $\mathrm{V}$ Gorodishchenskom, Dubovskom, Oktyabrskom i Kletskom rayonakh Volgogradskoy oblasti v 2006 godu [Report on Archaeological Research Conducted by the Volgo-Akhtuba Archaeological Expedition of the Volgograd State Pedagogical University in Gorodishchensky, Dubovsky, Oktyabrsky and Kletsky Districts of the Volgograd Region in 2006]. Arkhiv VOKM.

53. Nebolsin P. Ocherki byta kalmykov Khoshoutovskogo ulusa [Essays on the Life of the Kalmyks of the Khoshoutovsky Ulus]. Saint Petersburg, Tipografiya K. Kraya, 1852. 192 p.

54. Nekachalov V.V. Patologiya kostey $i$ sustavov. Rukovodstvo [Pathology of Bones and Joints. Manual]. Saint Petersburg, Sotis Publ., 2000. $288 \mathrm{p}$.

55. Pererva E.V. Paleopatologiya pozdnikh sarmatov iz mogilnikov Esaulovskogo Aksaya [Paleopathology of Late Sarmatians from the Burial Grounds of the Esaulovsky Aksai]. OPUS: Mezhdistsiplinarnye issledovaniya $v$ arkheologii [OPUS: Interdisciplinary Research in Archaeology]. Moscow, Izd-vo IA RAN, 2002, iss. 1-2, pp. 141-152.

56. Pererva E.V. Naselenie sarmatskoy epokhi po antropologicheskim materialam iz mogilnikov 
Nizhnego Povolzhya i Nizhnego Dona: dis. ... kand. ist. nauk [Population of the Sarmatian Epoch according to Anthropological Materials from the Burial Mounds of the Lower Volga and the Lower Don. Cand. hist. sci. diss.]. Moscow, 2005. 603 p.

57. Pererva E.V. Rentgenologicheskoe issledovanie deformirovannykh cherepov epokhi Sredney Bronzy s territorii Nizhnego Povolzhya (paleopatologicheskiy aspekt) [X-ray Study of Deformed Skulls of the Middle Bronze Age from the Lower Volga Region (Paleopathological Aspect)]. Vestnik Volgogradskogo gosudarstvennogo universiteta. Seriya 4, Istoriya. Regionovedenie. Mezhdunarodnye otnosheniya [Science Journal of Volgograd State University. History. Area Studies. International Relations], 2013, no. 2 (24), pp. 7-19. DOI: http://doi.org/10.15688/jvolsu4.2013.2.1.

58. Pererva E.V. Rentgenologicheskoe issledovanie deformirovannykh cherepov zolotoordynskogo vremeni s territorii Nizhnego Povolzhya (paleopatologicheskiy aspekt) [X-ray Study of Deformed Skulls of the Golden Horde Time from the Territory of the Lower Volga Region (Paleopathological Aspect)]. Vestnik arkheologii, antropologii $i$ etnografii [Bulletin of Archaeology, Anthropology and Ethnography], 2015, no. 2 (29), pp. 98-114.

59. Podzemskaya N.M., ed. Plinius Maior. Estestvennaya istoriya [Plinius Maior. Natural History]. Antichnaya geografiya [Ancient Geography]. Moscow, Geografgiz Publ., 1953, pp. 238-262.

60. Nefedkin A.K., ed. Polien. Strategemy [Polien. Strategies]. Saint Petersburg, Evraziya Publ., 2002. $608 \mathrm{p}$.

61. Apta S.K., ed. Pomponius Mela. Mestopolozhenie zemli [Pomponius Mela. Location of the Land]. Antichnaya geografiya [Ancient Geography]. Moscow, Geografgiz Publ., 1953, pp. 176-238.

62. Pryamukhin A.N. Otchet ob arkheologicheskikh issledovaniyakh mogilnika Sokhrannyy v Nekhaevskom rayone Volgogradskoy oblasti v 2015 godu [Report on Archaeological Research of the Sokhrannyy Burial Mound in the Nekhaevsky District of the Volgograd Region in 2015]. Volgograd, 2017. 122 p. Arkhiv VOKM.

63. Pustynnikov V.M. Lobnyy giperostoz kak proyavlenie vozrastnykh izmeneniy $\mathrm{v}$ kostyakh cherepa [Frontal Hyperostosis as a Manifestation of Age-Related Changes in Skull Bones]. Tyumenskiy meditsinskiy zhurnal [Tyumen Medical Journal], 2014, vol. 16 , no. 2 , p. 30.

64. Shastina N.P., ed. Puteshestvie v vostochnye strany Plano Karpini i Rubruka [A Trip of Plano Carpini and Rubruk to the Eastern Countries]. Moscow, Gos. izd-vo geogr. lit-ry, 1957. 272 p.

65. Sergatskov I.V. Otchet o raskopkakh kurganov bliz s. Tsarev v 1998 g. [Report on the
Excavation of Mounds near the Village Tsarev in 1998]. Arkhiv arkheologicheskoy laboratorii VolGU [Archive of the Archaeological Laboratory of VolSU]. 66. Sergatskov I.V. Sarmatskie kurgany na Ilovle [Sarmatian Mounds on the Ilovlya River]. Volgograd, Izd-vo VolGU, 2000. $396 \mathrm{p}$.

67. Sergatskov I.V. Otchet o raskopkakh kurgannogo mogilnika Olkhovka I na trasse stroitelstva magistralnogo gazoprovoda «Pochinki-Izobilnoe». Volgograd, $2003 \mathrm{~g}$. [Report on the Excavations of the Burial Mound Olkhovka I on the Route of Construction of the Main Gas Pipeline Pochinki-Izobilnoe. Volgograd, 2003]. Arkhiv arkheologicheskoy laboratorii VolGU [Archive of the Archaeological Laboratory of VolSU], $193 \mathrm{~L}$.

68. Sokolova M.A. Obraz zhizni i gormonalnye narusheniya na primere sarmatskikh plemen [Lifestyle and Hormonal Disorders on the Example of Sarmatian Tribes]. Ekologiya i demografiya cheloveka $v$ proshlom i nastoyashchem. Materialy Tretyikh antropologicheskikh chteniy $k$ 75-letiyu so dnya rozhdeniya akademika V. P. Alekseeva [Ecology and Demography of Man in the Past and the Present. Materials of the Third Anthropological Readings Dedicated to the $75^{\text {th }}$ Birth Anniversary of Academician V.P. Alekseev]. Moscow, Entsikl. ros. dereven Publ., 2004, pp. 188-190.

69. Latyshev V.V., ed. Saint Sidonius Apollinaris. Stikhotvoreniya [Saint Sidonius Apollinaris. Poetry]. VDI [Journal of Ancient History], 1949, no. 4 (30), pp. 288-289.

70. Stratanovskiy G.A., ed. Strabo. Geografiia: $v 17 \mathrm{kn}$. [Strabo. Geography: in 17 books]. Moscow, Ladomir Publ., 1994. 944 p.

71. Publius Cornelius Tacitus. Annaly. Malye proiszvedeniya. Istoriya [Annals. Brief Works. History]. Moscow, AST Publ.; Ladomir Publ., 2002. $811 \mathrm{p}$.

72. Firshtein B.V., Tot T.A. Antropologicheskie dannye $k$ voprosu o velikom pereselenii narodov avary $i$ sarmaty [Anthropological Data on the Issue of Great Migration of the Peoples of Avars and Sarmatians]. Leningrad, Nauka Publ., 1970. 201 p.

73. Kondratyeva S.N., ed. Flavius Vopiscus. Vlasteliny Rima: Biografii rimskikh imperatorov ot Adriana do Diokletiana [The Lords of Rome: Biographies of the Roman Emperors from Adrian to Diocletian]. Moscow, Nauka Publ., 1992, pp. 298-310.

74. Khazanov A.M. Sotsialnaya istoriya skifov [The Social History of the Scythians]. Moscow, Nauka Publ., 1975. 336 p.

75. Yules M., Khollo I. Diagnostika $i$ patofiziologicheskie osnovy neyroendokrinnykh zabolevaniy [Diagnosis and Pathophysiological Basis of Neuroendocrine Diseases]. Budapesht, Izd-vo Akademii nauk Vengrii, 1976. 882 p. 
76. Yablonskiy L.T. Antropologicheskie dannye $\mathrm{k}$ etnogenezu narodov Povolzhya (Po materialam Povolzhskoy ekspeditsii) [Anthropological Data to the Ethnogenesis of the Volga Region's Peoples (Based on the Materials of the Volga Expedition]. Nizhnevolzhskiy arkheologicheskiy vestnik [The Lower Volga Archaeological Bulletin], 2002, iss. 5, pp. 24-46.

77. Anderson T. An Anglo-Saxon case of hyperostosis frontalis interna from Sarre. Kent. Journal of Paleopathology, 1994, no. 6 (1), pp. 29-34.

78. Anton S.C. Endocranial Hyperostosis in Sangiran 2, Gibraltar 1, and Shanidar 5. American journal of physical anthropology, 1997, no. 102, pp. 111-122.

79. Armelagos G.J., Chrisman O.D. Hyperostosis frontalis interna: A Nubian case. American Journal of Physical Anthropology, 1988, no. 76, pp. 25-28.

80. Attanasio F., Giantin V., Manzato E. Full Penetrance of Morgagni-Stewart-Morel Syndrome in a 75-Year-Old Woman: Case Report and Review of the Literature. J. Clin. Endocrinol. Metab., February 2013, no. 98 (2), pp. 453-457.

81. Bebel A., Golijewskaja A. A case of hyperostosis frontalis interna from Deir el-Bahari, Egypt. Bioarchaeology of the Near East, 2015, no. 9, pp. $45-54$.

82. Caughey J.E. The etiology of hyperostosis cram! (Metabolic craniopathy). The Journal of Bone and Joint Surgery, 1958, vol. 40 B, no. 4, pp. 701-721.

83. Chudá E. P., Dornhoferova M. Hyperostosis frontalis interna $-\mathrm{a}$ find in women individual from Modern Times (St. Martin Cathedral, Spisska Kapitula, Slovakia). Antropowebzin, 2011, no. 2, pp. 97-101.

84. Devriendt W., Piercecchi-Marti M. D., Ardagna Y., Mahieu E., Hershkovitz I., Signoli M., Dutour O. Two Neolithic Cases of Hyperostosis Frontalis Interna. International Journal of Osteoarchaeology, 2004, no. 14, pp. 414-418.

85. Djonic D., Nikolic Sl., Ivovic M., Djuric M. Hyperostosis Frontalis Interna in Postmenopausal Women - Possible Relation to Osteoporosis. Women \& Health, 2016, pp. 1-23.

86. Flohr S., Witzel C. Hyperostosis frontalis interna-A marker of social status? Evidence from the Bronze-Age "high society" of Qatna, Syria. HOMOJournal of Comparative Human Biology, 2011, no. 62, pp. 30-43.

87. Garralda M.D., Maureille B., Vandermeersch B. Hyperostosis frontalis interna in a Neandertal from Marillac (Charente, France). Journal of Human Evolution, 2014, pp. 1-9.

88. Ginsburg V.V. An Anthropological Characterization of the Sarmatians in the Volga Area. Annales historic-Naturales Musei Nationalis
Hungarici (Pars Anthropologica). Hungury, 1968, vol. 60, pp. 307-311.

89. Glab H., Szostek K., Kaczanowski K. Hyperostosis frontalis interna, a genetic disease? Two medieval cases from Southern Poland. HOMO-Journal of Comparative Human Biology, 2006, no. 57, pp. 19-27.

90. Hajdu T., Fóthi E., Bernert Zs., Molnár E., Lovász G., Kõvári I., Köhler K., Marcsik A. Appearance of hyperostosis frontalis interna in some osteoarcheological series from Hungary. HOMO Journal of Comparative Human Biology, no. 60 (3), pp. 185-205. DOI: 10.1016/j.jchb.2008.07.004.

91. Hawkins T.D., Martin L. Incidence of hyperostosis frontalis interna in patients at a general hospital and at a mental hospital. Journal of Neurol. Neurosurg. Psychiat., 1965, no. 28, pp. 171-174.

92. Hershkovitz I., Greenwald Ch., Rothschild Br.M., Latimer Br., Dutour O., Jellema L.M., Wish-baratz S. Hyperostosis Frontalis Interna: An Anthropological Perspective. American journal of physical anthropology, 1999, no. 109, pp. 303-325.

93. Koller M.F., Papassotiropoulos A., Henke K., Behrends Br., Noda Sh., Kratzer Ad., Hock Chr., Hofmann M. Evidence of a Genetic Basis of Morgagni-StewartMorel Syndrome. A Case Report of Identical Twins. Neurodegenerative Disease, 2005, no. 2, pp. 56-60.

94. Korja M., Kaasinen V., LamusuoS., Marttila R.J., Parkkola R. Hyperostosis frontalis interna as a novel finding in Unverricht-Lundborg disease. Neurology, March 27, 2007, pp. 1077-1078.

95. Mant M. Paleopathology of human remains at ancient Mendes (Tell er-Rub'a), Egypt. Bioarcheology of the Near East, 2014, no. 8, pp. 1-27.

96. May H., Peled N., Dar G., Cohen H., Abbas J., Medlej B., Hershkovitz I. Hyperostosis frontalis interna: criteria for sexing and aging a skeleton. Int. J. Legal Med., 2011, no. 125, pp. 669-673.

97. MayH., Mali Y., Dar G., Abbas J., Hershkovitz I., Peled N. Intracranial Volume, Cranial Thickness, and Hyperostosis Frontalis Interna in the Elderly. American journal of human biology, 2012, no. 24, pp. 812-819.

98. Molnár E., Marcsik A. Paleopathological evaluation of Hungarian skeletal remains from the $7^{\text {th }}-$ $9^{\text {th }}$ centuries AD. Antropofagia Portuguesa, 2002, no. 19 , pp. 85-99.

99. Moore S. Hyperostosis Cranii (Cranial Hyperostosis). Springfield, C.C. Thomas, 1955. 226 p.

100. Mulher D.M., Wilczak C.A., Dudar J.Ch. Brief Communication: Unusual Finding at Pueblo Bonito: Multiple Cases of Hyperostosis Frontalis Interna. American Journal of Physical Anthropology, 2006, no. 130 , pp. 480-484.

101. Nowakowski D., Kwiatkowska B. A case of Hyperostosis frontalis interna (HFI) in a medieval skeleton from Lower Silesia (Poland). Journal of Paleopathology, 2005, no. 17 (1), pp. 5-9. 
102. Ortner D.J., Putschar W.G. Identification of pathological conditions in human skeletal remains. Smithonian contributions anthropological. Washington, Smithonian Institution Press, 1981, no. 28, pp. 57-59.

103. Powers N. Human osteology method statement. London, Museum of London, 2008. 64 p.

104. Raikos A., Paraskevas G.K., YusufF., Kordali P., Meditskouc S., Al-Haj A., Brand-Saberi B. Etiopathogenesis of hyperostosis frontalis interna: A mystery still. Annals of Anatomy, 2011, no. 193, pp. 453-458.

105. Roberts Ch., Manchester K. The Archaeology of Disease. Manchester, The History Press, 2010.338 p.

106. Ruhli F. J., Boni T., Henneberg M. Hyperostosis frontalis interna: archaeological evidence of possible microevolution of human sex steroids? HOMO - Journal of Comparative Human Biology, 2004, no. 55, pp. 91-99.

107. Shahin A.A., Alhoseiny S., Aldali M. Hyperosto sis frontalis interna: An Egyptian case referred to the second dynas y (2890-2650 BC) from Tarkhan-Egypt. The Egyptian Rheumatologist, 2014, no. 36, pp. 41-45.

108. She R., Szakacs J. Hyperostosis Frontalis Interna: Case Report and Review of Literature. Annals of Clinical \& Laboratory Science, 2004, vol. 34, no. 2, pp. 206-208.

109. Singh K., Shrinuvasan S., Chidambaram R. Hyperostosis frontalis interna - a rare Benign incidental finding. Indian Journal of Medical Case Reports, 2017, vol. 6(2), pp. 15-17.

110. Smith S., Hemphill R. E. Hyperostosis frontalis interna. J. Neurol. Neurosurg. Psychiat, 1956, no. 19 , pp. $42-45$.

111. The Cambridge Encyclopedia of Human Paleopathology by Arthur C. Aufderheide \& Conrado Rodriguez-Martin. United Kingdom, Cambridge University Press, 1998. 478 p.

112. Toase L. An osteological analysis of skeletons from the Roman necropolis of Apulum, Alba Iulia, Romania. Buletinul Cercurilor Ştiințifice Studențeşti, 2014, no. 20, pp. 83-96.

113. Trelles O.J. Mario Mendes Sindrome de Stewart-Morel (Hiperostosis Frontal interna). Santiago, Prensas de la universidad de chile, 1936, pp. 53-64.

114. Waldron T. Paleopathology. Cambridge, Cambridge University Press, 2009. 279 p.

115. Watrous A.C., Anton S.C., Plourde A.M. Hyperostosis frontalis interna in ancient Egyptians. American Journal of Physical Anthropology, 1993, vol. 16 (suppl.) 205.

116. Weiss E. Paleopathology in Perspective. Bone health and disease through time. Lanham; Boulder; New York; London, 2015. 251 p.

117. Yaxiong Li, Xin Wang, Yan Li. Hyperostosis Frontalis Interna in a Child with Severe Traumatic Brain Injury. Child Neurology Open, 2017, vol. 4, pp. 1-4.

\section{Information about the Authors}

Evgeniy V. Pererva, Candidate of Sciences (History), Head of Department for Science and Logistics, Volgograd Institute of Management - Branch of Russian Presidential Academy of National Economy and Public Administration, Gagarina St., 8, 400131 Volgograd, Russian Federation, perervafox@mail.ru, https://orcid.org/0000-0001-8285-4461

Vladimir I. Moiseev, Researcher of Laboratory of Archaeological Research, Volgograd State University, Prosp. Universitetsky, 100, 400062 Volgograd, Russian Federation, v.moiseev@volsu.ru, https://orcid.org/0000-0002-5110-733X

\section{Информация об авторах}

Евгений Владимирович Перерва, кандидат исторических наук, начальник научно-организацонного отдела, Волгоградский институт управления - филиал Российской академии народного хозяйства и государственной службы (РАНХиГС), ул. Гагарина, 8, 400131 г. Волгоград, Российская Федерация, perervafox@mail.ru, https://orcid.org/0000-0001-8285-4461

Владимир Иванович Моисеев, научный сотрудник лаборатории археологических исследований, Волгоградский государственный университет, просп. Университетский, 100, 400062 г. Волгоград, Российская Федерация, v.moiseev@volsu.ru, https://orcid.org/0000-0002-5110-733X 